\title{
PURA-Related Developmental and Epileptic Encephalopathy
}

\author{
Phenotypic and Genotypic Spectrum
}

Katrine M. Johannesen, MD, PhD, Elena Gardella, MD, PhD, Cathrine E. Gjerulfsen, MD, Allan Bayat, MD, Rob P.W. Rouhl, MD, Margot Reijnders, MD, Sandra Whalen, MD, Boris Keren, MD, PhD, Julien Buratti, MSc, Thomas Courtin, MD, Klaas J. Wierenga, MD, Bertrand Isidor, MD, Amélie Piton, MD, Laurence Faivre, MD, Aurore Garde, MD, Sébastien Moutton, MD, Frédéric Tran-Mau-Them, MD, Anne-Sophie Denommé-Pichon, MD, Christine Coubes, MD, Austin Larson, MD, Michael J. Esser, MD, Juan Pablo Appendino, MD, Walla Al-Hertani, MD, Beatriz Gamboni, MD, Alejandra Mampel, MD, Lía Mayorga, MD, PhD, Alessandro Orsini, MD, PhD, Alice Bonuccelli, MD, Agnese Suppiej, MD, Julien Van-Gils, MD, Julie Vogt, MD, Simona Damioli, MD, Lucio Giordano, MD, Stephanie Moortgat, MD, PhD, Elaine Wirrell, MD, Sarah Hicks, MD, Usha Kini, MD, Nathan Noble, DO, Helen Stewart, MD, Shailesh Asakar, MD, Julie S. Cohen, MD, SakkuBai R. Naidu, MD, Ashley Collier, MD, Eva H. Brilstra, MD, Mindy H. Li, MD, Casey Brew, MD, Stefania Bigoni, MD, Davide Ognibene, MD, Elisa Ballardini, MD, Claudia Ruivenkamp, MD, Raffaella Faggioli, MD, Alexandra Afenjar, MD, Diana Rodriguez, MD, David Bick, MD, Devorah Segal, MD, PhD, David Coman, MD, Boudewijn Gunning, MD, Orrin Devinsky, MD, Laurie A. Demmer, MD, Theresa Grebe, MD, Dario Pruna, MD, Ida Cursio, MD, Lynn Greenhalgh, MD, MSc, Claudio Graziano, MD, PhD, Rahul Raman Singh, MD, Gaetano Cantalupo, MD, Marjolaine Willems, MD, Sangeetha Yoganathan, MD, Fernanda Góes, MD, Richard J. Leventer, MD, PhD, Davide Colavito, MD, Sara Olivotto, MD, Barbara Scelsa, MD, Andrea V. Andrade, MD, Kelly Ratke, PhD, Farha Tokarz, MD, Atiya S. Khan, MD, Clothilde Ormieres, MD, William Benko, MD, Karen Keough, MD, Sotirios Keros, MD, Shanawaz Hussain, MD, Ashlea Franques, MD, Felicia Varsalone, MD, Sabine Grønborg, MD, Cyril Mignot, MD, PhD, Delphine Heron, MD, Caroline Nava, MD, PhD, Arnaud Isapof, MD, Felippe Borlot, MD, Robyn Whitney, MD, Anne Ronan, MD, Nicola Foulds, MD, Marta Somorai, MD, John Brandsema, MD, Katherine L. Helbig, MSc, Ingo Helbig, MD, PhD, Xilma R. Ortiz-González, MD, Holly Dubbs, MD, Antonio Vitobello, PhD, Mel Anderson, MSc, Dominic Spadafore, MSc, David Hunt, MD, Rikke S. Møller, MSc, PhD, Guido Rubboli, MD, PhD, * and the PURA study group

Neurol Genet 2021;7:e613. doi:10.1212/NXG.0000000000000613

\begin{abstract}
*Guido Rubboli, MD, PhD, is designated as the last author of this article.
From the Department of Epilepsy Genetics and Personalized Treatment (K.M.J., E.G., C.E.G., A.B., R.S.M., G.R.), The Danish Epilepsy Centre Filadelfia, member of ERN EpiCARE, Dianalund; Institute for Regional Health Research (K.M.J., E.G., A.B., R.S.M), University of Southern Denmark, Odense; Department of Neurology (R.P.W.R.), Maastricht University Medical Centre (MUMC+); Academic Centre for Epileptology Kempenhaeghe/MUMC+ (R.P.W.R.), Maastricht; School for Mental Health and Neuroscience (R.P.W.R.), Maastricht University; Department of Clinical Genetics (M.R.), Maastricht University Medical Center, the Netherlands; APHP, Sorbonne Université (S.W.), Hôpital Armand Trousseau, UF de Génétique Clinique, Centre de Référence Anomalies du Développement et Syndromes Malformatifs, Paris, France; Department of Genetics (B.K., J.B., T.C., C.N.), Pitié-Salpêtrière hospital, APHP, Sorbonne Université, Paris, France; Department of Clinical Genomics (K.J.W.), Mayo Clinic Florida, Jacksonville; Service de Génétique Médicale (B.I., A.P., A.-S.D.-P.), CHU de Nantes; Centre de Référence Anomalies du Développement et Syndromes Malformatifs (L.F., A.G., S.M.), FHU TRANSLAD, CHU Dijon; INSERM UMR1231 (L.F., A.G., S.M., F.T.M.-T., A.V.), GAD team, Université de Bourgogne-Franche Comté, Dijon; Unité Fonctionnelle dinnovation diagnostique des maladies rares (F.T.-M.-T., A.V.), Pôle de Biologie, FHU-TRANSLAD, CHU Dijon Bourgogne; Department of Medical Genetics (C.C., M.W.), Rare Diseases and Personalized Medicine, CHU Montpellier, France; Childrens Hospital Colorado (A.L.), Anschutz Medical Campus, Aurora, CO; Division of Clinical Neuroscience (M.J.E., J.P.A.), Department of Pediatrics, Alberta, Canada; Alberta Childrens Hospital (I.P.A., F.B.), Cumming School of Medicine, University of Calgary, Alberta, Canada; Department of Pediatrics (W.A.-H.), Division of Genetics and Genomics, Boston Childrens Hospital and Harvard Medical School, MA; Instituto de Neurología Infanto Juvenil (B.G.), Neuroinfan; Instituto de GeneticaHospital Universitario (A.M.), Universidad Nacional de Cuyo; Instituto de Histología y Embriología de Mendoza (IHEM) (L.M.), Universidad Nacional de Cuyo, Mendoza, Argentina; Azienda Ospedaliera Universitaria Pisana (A.O.); Neuropaediatric Section (A.B.), Pediatric Department, Santa Chiara University Hospital, Pisa; Department of Medical Sciences- Pediatric Section (A.S.), University of Ferrara, Italy; CHU Bordeaux (J.V.-G.), Bordeaux, France; West Midlands Regional Genetics Service (J.V.), Birmingham Women's and Children's Hospital, Birmingham, UK; Child Neuropsychiatric Division (S.D., L.G.), Spedali Civili, Brescia, Italy; Institut de Pathologie et de Génétique (IPG) (S.M.), Gosselies, Belgium; Divisions of Child and Adolescent Neurology and Epilepsy (E.W.), Department of Neurology, Mayo Clinic, Rochester, MN; Oxford Centre for Genomic Medicine (S.H., H.S.); Oxford University Hospitals NHS Trust (U.K.), United Kingdom; Blank Children's Developmental Center (N.N.), Unity Point Health, West Des Moines, IA; Sutter Medical Centre (S.A.), Sacramento, CA; Kennedy Krieger Institute (I.S.C.); Johns Hopkins University (S.R.N.), Baltimore, MD; Provincial Medical Genetics Program (A.C.), St. Johns Medical Center, NL, Canada; University Medical Center Utrecht (E.H.B.), Utrecht, the Netherlands; Rush University Medical Center (M.H.L., C.B.), Chicago, IL; Medical Genetic Unit (S.B., D.O.), Maternal and Child Department, Ferrara University Hospital; Medical Science Department (D.O.), Ferrara University; Neonatal Intensive Care Unit (E.B.), Pediatric Section, Department of Medical Sciences, Ferrara University, Italy; Department of Clinical Genetics (C.R.), LUMC, Leiden, the Netherlands; Pediatric Unit, Maternal and Child Department (R.F.), Ferrara University Hospital, Italy; APHP Trousseau (A.A., C.M., D.H.); Service de Neuropédiatrie (D.R., A.I.), Hopital Trousseau, Sorbonne Université, APHP.SU, Paris, France; HudsonAlpha Institute for Biotechnology (D.B.), Huntsville, AL; Department of Pediatrics (D.S., S.K.), Weill Cornell Medicine, New York; Queensland Children's Hospital (D.C.), Brisbane, QL, Australia; Department of Neurology (B.G.), Stichting Epilepsie Instellingen Nederland, Zwolle, the Netherlands; Department of Neurology (O.D.), NYU School of Medicine; Atrium Healths Levine Childrens Hospital (L.A.D.), Charlotte, NC; Phoenix Childrens Hospital (T.G.), the University of Arizona College of Medicine; Division of Child Neurology and Psychiatry (D.P.), Azienda Ospedaliero Universitaria; Neurology and Epileptology Unit (I.C.), Pediatric Department, Brotzu Hospital Trust, Cagliari, Italy; Liverpool Centre for Genomic Medicine (L.G., G.R.), Liverpool Womens NHS Foundation Trust, Liverpool, United Kingdom; U.O. Genetica Medica (C.G.), Policlinico S. Orsola-Malpighi, Bologna, Italy; Department of Children's neurosciences (R.R.S.), Guys and ST. Thomas' NHS foundation trust, London United Kingdom; Department of Child Neuropsychiatry (G.C.), University of Verona, Italy; Christian Medical College (S.Y.), Vellore, India; Neurology Pediatric Unit (F.G.), Pediatric Department, Fernandes Figueira Institute, Fiocruz, Brazil; Royal Childrens Hospital (F.J.L.), Melbourne, Australia; Research \& Innovation S.r.I. (D.C.), Padova; Pediatric Neurology Unit (S.O., B.S., F.V.), V. Buzzi Childrens Hospital, Milan, Italy; Department of Paediatrics (A.V.A.), London Health Science Centre/Schulich School of Medicine and Dentisty, University of Western Ontario, London, ON, Canada; Ambry Genetics (K.R.), Aliso Viejo, CA; Advocate Lutheran General Hospital (F.T.), Park Ridge, IL; PPG Pediatric Neurology (A.S.K.), Parkview Health, Fort Wayne, IN; Department of Medical Genetics (C.O.), AP-HP, Necker-Enfants Malades Hospital, Paris, France; Department of Neurology (W.B.), UC Davis, Sacramento, CA; Department of Pediatrics (K.K.), Texas A\&M University Medical School, Austin; Leeds General Infirmary (S.H,), United Kingdom; Thompson River Pediatrics (A.F.), Johnstown, CO; Department of Neuropediatrics (S.G.), University Hospital Copenhagen, Denmark; Division of Neurology (F.B., R.W.), Department of Paediatrics, The Hospital for Sick Children, Toronto, Ontario, Canada; Hunter Genetics Unit, Waratah, Australia (A.R.); Wessex Clinical Genetics Service, Princess Anne Hospital, Southampton, United Kingdom (N.F., D.H.); KBO-Kinderzentrum München, Munich, Germany (M.S.); Division of Neurology, Epilepsy Neurogenetics Initiative, Childrens Hospital of Philadelphia (J.B., K.L.H., I.H., X.R.O-G, H.D.); Perelman School of Medicine, Philadelphia, PA (J.B.); PURA Syndrome Foundation, Greensborough, Australia (I.H., M.A., D.S.); PURA Syndrome Foundation, Kansas City, MO (I.H., D.S.).
\end{abstract}

Go to Neurology.org/NG for full disclosures. Funding information is provided at the end of the article.

The Article Processing Charge was funded by The PURA Syndrome Foundation.

This is an open access article distributed under the terms of the Creative Commons Attribution-NonCommercial-NoDerivatives License 4.0 (CC BY-NC-ND), which permits downloading and sharing the work provided it is properly cited. The work cannot be changed in any way or used commercially without permission from the journal. 


\section{Glossary}

AA = amino acid; ASM = antiseizure medication; DEE = developmental and epileptic encephalopathy; ESES = electrical status epilepticus during sleep; GTC = generalized tonic-clonic; ID = intellectual disability; KO = knockout; LEV = levetiracetam; PTV = protein-truncating variant; PURA = purine-rich element-binding protein A; SUDEP = sudden unexpected death in epilepsy; $\mathbf{T P M}=$ topiramate; $\mathbf{V P A}=$ valproate.

\section{Abstract}

\section{Background and Objectives}

Purine-rich element-binding protein A (PURA) gene encodes Pur- $\alpha$, a conserved protein essential for normal postnatal brain development. Recently, a PURA syndrome characterized by intellectual disability, hypotonia, epilepsy, and dysmorphic features was suggested. The aim of this study was to define and expand the phenotypic spectrum of PURA syndrome by collecting data, including EEG, from a large cohort of affected patients.

\section{Methods}

Data on unpublished and published cases were collected through the PURA Syndrome Foundation and the literature. Data on clinical, genetic, neuroimaging, and neurophysiologic features were obtained.

\section{Results}

A cohort of 142 patients was included. Characteristics of the PURA syndrome included neonatal hypotonia, feeding difficulties, and respiratory distress. Sixty percent of the patients developed epilepsy with myoclonic, generalized tonic-clonic, focal seizures, and/or epileptic spasms. EEG showed generalized, multifocal, or focal epileptic abnormalities. Lennox-Gastaut was the most common epilepsy syndrome. Drug refractoriness was common: 33.3\% achieved seizure freedom. We found 97 pathogenic variants in PURA without any clear genotype-phenotype associations.

\section{Discussion}

The PURA syndrome presents with a developmental and epileptic encephalopathy with characteristics recognizable from neonatal age, which should prompt genetic screening. Sixty percent have drug-resistant epilepsy with focal or generalized seizures. We collected more than 90 pathogenic variants without observing overt genotype-phenotype associations.

Purine-rich element-binding protein A (PURA) gene, located on chromosome 5q31, encodes a single-exon transcript that results in a highly conserved 322 amino acid (AA) protein, Pur- $\alpha .{ }^{1}$ Pur- $\alpha$ is essential for normal postnatal brain development, as well as proliferation of neuronal cells and synapse formation. ${ }^{2}$ Pur- $\alpha$ knock-out mice display a severe phenotype with neurologic dysfunction, including spontaneous seizures, tremor, and early death. ${ }^{3}$ The Pur- $\alpha_{+/-}$mouse shows hypotonia, gait deficits, and memory dysfunction, correlating with a loss of neurons in the cerebellum and hippocampus. ${ }^{4}$

Initially defined as the $5 \mathrm{q} 31.3$ microdeletion syndrome, after the discovery of point variants, the term PURA syndrome (OMIM \#616158) was acknowledged, and more than 70 patients with pathogenic de novo variants in PURA have been published to date. ${ }^{2,5-15}$ PURA phenotypes are heterogeneous and can include moderate to severe intellectual disability (ID), hypotonia, movement disorders, epilepsy, dysmorphic facial features, and brain abnormalities. ${ }^{70}$ Most patients do not achieve independent walking and remain nonverbal. ${ }^{7}$ The neonatal period is often complicated by respiratory insufficiency and feeding difficulties because of pronounced hypotonia, and children often have an exaggerated startle response.?
Epilepsy is reported in approximately half of the patients, with seizure onset usually in infancy-early childhood, although the age at onset has a wide range. ${ }^{7}$ Seizure types are often refractory and are usually described as generalized tonic-clonic (GTC) seizures, absence of seizures, epileptic spasms, and tonic seizures, with the most commonly diagnosed epilepsy syndrome being Lennox-Gastaut syndrome. ${ }^{7}$ Specific treatment recommendations are not currently available.

Genotype-phenotype correlations in PURA syndrome have been inconsistent so far, and even within patients with identical variants, phenotype and severity can vary significantly. ${ }^{7}$

In this study, we report on 142 patients including 67 unpublished cases aiming to expand and further define the phenotypic and genotypic spectrum of the PURA syndrome, with particular focus on the epilepsy phenotype.

\section{Methods}

\section{Patients}

Patients were recruited from genetic and epilepsy clinics worldwide. Most of the patients were referred through the PURA 
Syndrome Foundation. Genetic variants were assessed for pathogenicity according to the American College of Medical Genetics and Genomics guidelines, ${ }^{16}$ including criteria such as being nonsynonymous, splice-site altering, nonsense, or frameshift changes, predicted damaging by 1 or more prediction software (Poly-Phen-2, SIFT, and MutationTaster), not seen in controls in the GnomAD browser and occurring de novo. Pathogenic and likely pathogenic variants were included. Deletions were not included. Sanger sequencing was used to confirm all variants and perform segregation analysis.

Clinical characteristics were assessed through a standardized phenotyping sheet and included data on neuroimaging and neurophysiology, as well as treatment response. Treatment response was assessed by the referring clinician as seizure free (no seizure for $>6$ months at the time of the referral of the patient to the study), seizure reduction, no effect or seizure aggravation. Seizures were classified according to the latest proposals of the International League Against Epilepsy commission on classification. ${ }^{17,18}$ EEG data were collected by means of standard EEG recording or daytime video-polygraphic recording, including wakefulness and sleep. Longitudinal EEG evaluation over time was not performed because of lack of data. Whenever possible, original EEG studies were evaluated by 2 neurologists with EEG expertise (E.G. and G.R.).

A PubMed search using the search term "PURA" was performed to extract data on previously published patients. Last search date: June 1, 2020.

\section{Statistical Analysis}

Clinical data were analyzed using Stata version 15.1 for Mac (StataCorp, College Station, TX). For continuous unmatched data, the Wilcoxon rank-sum (Mann-Whitney) was used. Significance was tested using a 2-tailed test of proportions, and significance was reached if $p<0.05$. The do-file used to perform the analysis is available on request.

\section{Standard Protocol Approvals, Registrations, and Patient Consents}

The local ethical committees approved this study. All patients or parents/legal guardians in case of minors signed informed consent.

\section{Data Availability}

Those eligible will be granted access to deidentified patient data in excel format, as well as do-files to Stata on request. Data will be stored for 6 months after publication. Those eligible includes independent researcher wishing to perform additional data analysis.

\section{Results}

Sixty-seven previously unpublished patients were included along with 75 previously published patients - 142 patients in total. Age at inclusion ranged from 5 months to 48 years (median 6 years). The total cohort is given in eTables 1 and 2 (links.lww.com/NXG/A448 and links.lww.com/NXG/A449).

\section{Clinical Features}

\section{Neonatal Period}

Data were available in 134 patients (94.4\%); 114 of the 134 patients (85.2\%) had congenital hypotonia and 72 of 134 (53.5\%) had respiratory difficulties, the most common being central sleep apneas, which required mechanical ventilation or supplementary oxygen in 19 of the 72 patients (26.9\%). Feeding difficulty was another common issue seen in 109 of the 134 patients $(81.3 \%)$, and it required gastrointestinal tube feeding in 42 of the 109 patients $(38.5 \%)$. Other features of the neonatal period included hypersomnolence (35/134, $26.1 \%)$, and hypothermia (15/134, 11.3\%).

\section{Childhood and Early Adulthood ( $<25$ Years of Age)}

Developmental milestones were delayed in all patients (analyzed in previously unpublished patients only, Table 1). At the time of inclusion, 47 patients achieved head control (70.1\%), median age 16 months. Forty-three patients were able to sit (56.6\%), median age 17.5 months. Thirty-four were able to walk with aid (50.7\%), and 25 were walking independently (37.3\%), median ages 5 and 3.5 years, respectively. Five patients regressed from walking to being nonambulatory. Communication skills were very limited in all the patients; $93.5 \%$ were nonverbal.

In childhood and early adulthood, hypotonia continued to be an overt clinical feature affecting 107 of the 134 patients (79.9\%) with PURA syndrome. Movement disorders such as dyskinesia, hand stereotypies, ataxia, and chorea-like movements were detected in 32 of the 134 patients (23.9\%). A pathologic startle response was present in 24 of 134 (17.9\%). Additional common disorders were strabismus $(28,20.9 \%)$, horizontal nystagmus not related to antiseizure medication (ASM) $(22,16.4 \%)$, and cortical vision impairment, $15(11.2 \%)$. In 8 of the 50 patients (16.0\%) without epilepsy, episodes with twitching or with staring, not associated with any EEG correlate, were considered of nonepileptic nature.

Other common characteristics included constipation (27/ $134,20.1 \%)$, scoliosis $(26 / 134,19.4 \%)$, hip dysplasia (21/ $134,15.7 \%)$, cardiac and large vessel abnormalities (15/134,

Table 1 Age of Achievement of Developmental Milestones in the PURA Syndrome

\begin{tabular}{lll}
\hline $\begin{array}{l}\text { Developmental } \\
\text { milestones }\end{array}$ & $\begin{array}{l}\text { Achieved in } \mathbf{n} \\
\text { patients (\%) }\end{array}$ & $\begin{array}{l}\text { Median age of } \\
\text { achievement (range) }\end{array}$ \\
\hline Head control & $47(70.1 \%)$ & 16 mo (8-24 mo) \\
\hline Rolling over & $44(65.7 \%)$ & 13.5 mo (6-18 mo) \\
\hline Sitting & $43(56.6 \%)$ & 17.5 mo (10 mo-3.5 y) \\
\hline Crawling & $37(55.2 \%)$ & 2.5 y $(1.5-4$ y) \\
\hline $\begin{array}{l}\text { Walking with } \\
\text { assistance }\end{array}$ & $34(50.7 \%)$ & 5 y $(2.5-10$ y) \\
\hline Walking & $25(37.3 \%)$ & 3 y $(1$ y 4 mo-12 y) \\
\hline
\end{tabular}

Abbreviation: PURA = purine-rich element-binding protein $\mathrm{A}$. 
$11.2 \%)$, dysphagia $(15 / 134,11.20 \%)$, delayed puberty (13/ $134,9.7 \%)$, and small stature $(12 / 134,9.0 \%)$.

\section{Adulthood ( $>25$ Years of Age)}

Nine patients were 25 years of age or older at the time of inclusion. All 9 patients had hypotonia. Three were capable of walking autonomously, 1 could walk with aid, and the remainder were nonambulant. All, but one, were nonverbal. Six had severe ID, while 3 had moderate ID.

\section{Early Mortality}

In our cohort, 4 patients were deceased: 1 (\#39) died at the age of 15 years because of sudden unexpected death in epilepsy (SUDEP), whereas 1 (\#40) died at the age of 3 years and 2 (\#70 and \#104) died in their twenties, in a state of severe general compromise after a relentless deterioration of neurologic conditions, ultimately because of respiratory distress. ${ }^{5,7}$ Of notice, 2 of the patients (\#39 and \#40) carry the same variant, i.e., c.812 814del, p.(Phe271del). Two additional patients with this variant have been published $\left(\# 108^{8}\right.$ and $\left.\# 109^{7}\right)$; however, at the time of publication, both patients were very young $(<1$ year), so the disease course was still unknown. A summary of the clinical features is available in Table 2.

Table 2 Clinical Features of the Total PURA Cohort

\begin{tabular}{ll}
\hline Clinical features & \\
\hline Sex, female/male (\%) & $93 / 64(59.2 \% / 40.8 \%)$ \\
\hline Age at inclusion, median (range) & $6 \mathrm{y}(5 \mathrm{mo}-48 \mathrm{y})$ \\
\hline Epilepsy (\%) & $84(59.2 \%)$ \\
\hline Age of epilepsy onset, median (range) & $3 \mathrm{y}(1 \mathrm{~d}-18 \mathrm{y})$ \\
\hline Most common seizure types (\%) & Myoclonic (22.5\%) \\
\hline Neurologic features & Focal (20.2\%) \\
\hline Neonatal period & $\mathrm{n}(\%)$ \\
\hline Hypotonia & \\
\hline Feeding difficulties & $121(85.2 \%)$ \\
\hline Respiratory distress & $115(81.0 \%)$ \\
\hline Hypersomnolence & $76(53.5 \%)$ \\
\hline Childhood to adulthood & $37(26.1 \%)$ \\
\hline Hypotonia & \\
\hline Strabismus & $25(17.6 \%)$ \\
\hline Nonepileptic episodes (twitching or staring) & $23(16.2 \%)$ \\
\hline Pathologic startle response & $34(23.9 \%)$ \\
\hline Movement disorder & $92(64.8 \%)$ \\
\hline Dysmorphic features & $4(2.8 \%)$ \\
\hline Death & \\
\hline & \\
\hline
\end{tabular}

Abbreviation: PURA = purine-rich element-binding protein A.

\section{Neuroimaging}

Half (51.4\%) of the patients showed changes in the MRIs. Most commonly, these changes included delayed myelination (38.5\%) and volume loss (14.1\%).

\section{Dysmorphology}

Ninety-two patients (64.8\%) displayed dysmorphic features. Facial photographs are shown in Figure 1. Subtle but recurrent similarities were observed including a hypotonic face, high anterior hairline, almond-shaped palpebral fissures, and full cheeks. A flat nasal bridge with a wide and triangular nasal tip, thickened nostrils, a well-defined philtrum, heavy eyebrows, and periorbital fullness was present in a subset of individuals.

\section{Epilepsy Phenotype}

Eighty-four patients (59.2\%) had epilepsy. The median age at seizure onset was 3 years, ranging from the first day of life to 18 years. Age at inclusion in the subgroup of patients with epilepsy was 9.6 years (vs 4.9 years in the subgroup without epilepsy, $p=0.0001$ ). Data on seizure types were available for 72 of the 84 patients (85.7\%). Heterogeneous seizure types were reported (Figure 1), with the most common being myoclonic seizures (22.5\%), GTC seizures (21.3\%), focal seizures (20.2\%) with secondary generalization (15.7\%), epileptic spasms (19.1\%), and atonic (14.6\%) and tonic seizures (12.4\%). Reflex seizures to auditory, visual, and somatosensory stimuli (such as touch, tooth brushing or hair brushing, pain, associated with evacuation) were reported in 6 patients (7.9\%) (\#17,\#20,\#31,\#35, \#91, and \#92, eTables 1 and 2, links.lww.com/NXG/A448 and links.lww.com/NXG/A449). ${ }^{8,9}$ Reflex seizures were described as myoclonic or atonic seizures, or "absence-like" episodes, and in some patients, they occurred for a transitory period (\#31). Overall, half (53.7\%) of the patients presented with various seizure types in different combinations, including either focal or generalized (such as absences, myoclonic, and GTC) seizure types in the same patient. A diagnosis of LennoxGastaut syndrome or West syndrome was made in 5 patients $(\# 79, \# 92$, \#97, \#99, and \#100) and 2 patients (\#19 and \#40), respectively. ${ }^{5,7,8} \mathrm{We}$ attempted to investigate whether early-onset ( $<12$ years) and later-onset ( $>12$ years) epilepsies presented with different phenotypes. These analyses were hampered by the unbalanced distribution of the available information in the 2 groups because seizure types and age at onset were reported in 64 patients with onset before or at the age of 12 years and in 6 patients with onset after the age of 12 years. Four of the 6 patients with epilepsy onset after 12 years presented with focal, focal and secondary GTC, or GTC. Patients with onset before the age of 12 years presented with heterogeneous seizure types in variable combinations.

\section{EEG}

EEG data were collected in 104 of the 142 patients (73.2\%), including in 67 of the 84 patients (79.8\%) with epilepsy. Abnormal EEGs, not further specified, were reported in 30 epileptic participants (44.7\%), whereas in 3 (4.4\%), the EEG was described as unremarkable. In the remaining 37 patients, background slowing was reported in 19 of 37 (51.3\%), whereas epileptic abnormalities were described as diffuse/generalized in 12 of the 37 patients (32.4\%), multifocal in 10 of the 37 patients (27\%), and focal in 7 of 

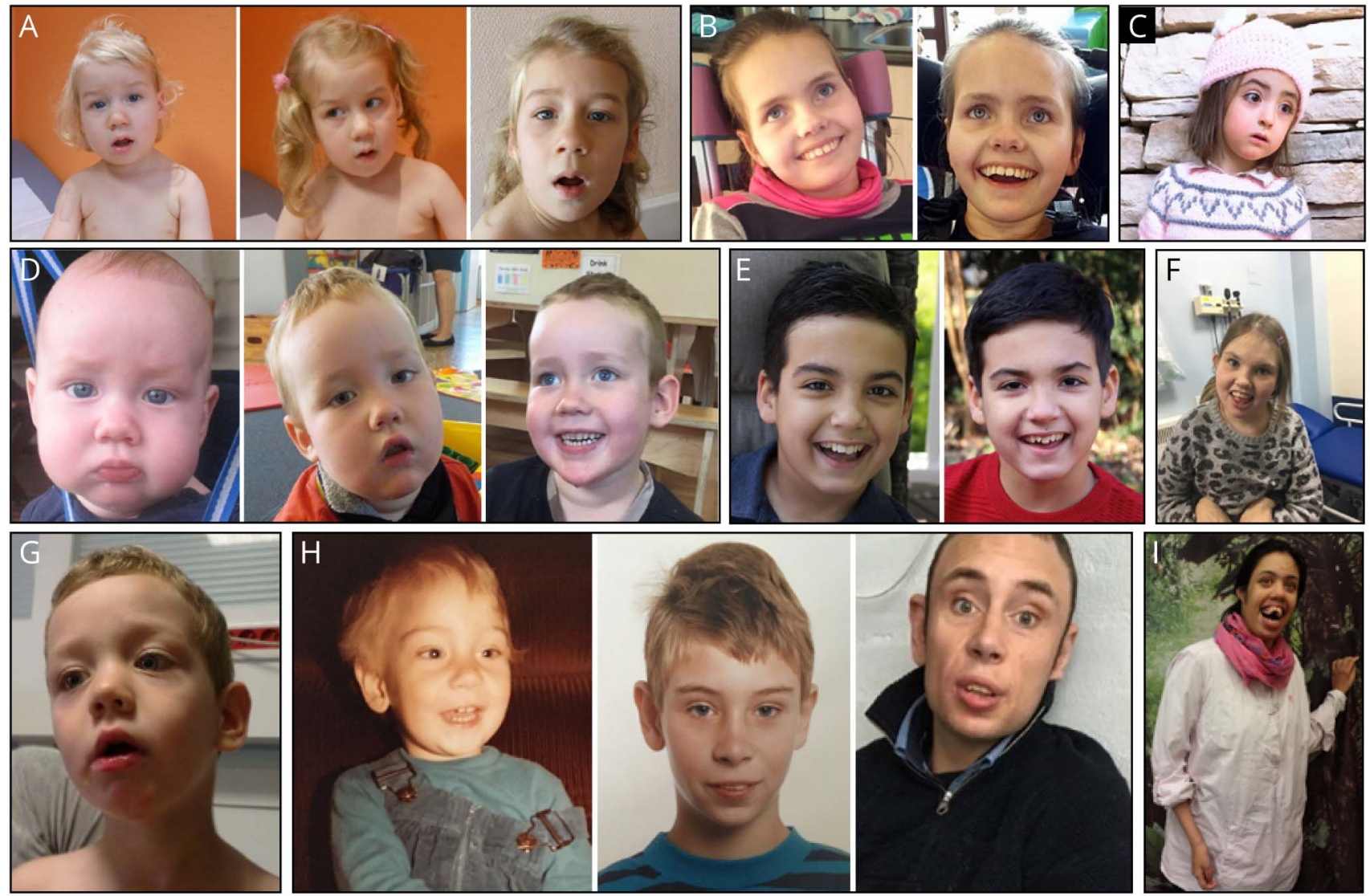

Faces of patients with pathogenic PURA variants. Recurrent similarities include a myopathic face, high anterior hairline, almond-shaped palpebral fissures, and full cheeks. A flat nasal bridge with a wide and triangular nasal tip, thickened nostrils, a well-defined philtrum, heavy eyebrows, and periorbital fullness was seen in a subset of individuals. PURA = purine-rich element-binding protein $\mathrm{A}$.

the 37 patients (18.9\%), respectively. Four children (10.8\%) presented with an excessive activation of the epileptic abnormalities during sleep (resembling an electrical status epilepticus during sleep [ESES] pattern), whereas hypsarrhythmia and burst suppression were observed in 3 patients (8.1\%) each (Figure 2).

EEG recordings were available also in 37 of the 57 patients (64.9\%) without epilepsy. It showed poorly organized/slowed background activity in 8 of the 37 patients $(21.6 \%)$, diffuse spikes in 1 of 37 (2.7\%), and focal spikes in 2 of 37 (5.4\%); in the remaining patients, it was diagnosed as abnormal not further specified in 1 of $37(2.7 \%)$ and unremarkable in 25 of 37 $(67.5 \%)$. At the time of the patient collection, none of the patient without epilepsy featuring a previously abnormal EEG was reported to have presented with epilepsy in the follow-up.

\section{Epilepsy Treatment}

Treatment response was evaluated in the patients with epilepsy from the previously unpublished cohort only (42 patients) because data were too sparse in the published patients.

Most of the patients $(28 / 42,66.7 \%)$ were still having seizures despite appropriate treatment with ASM. Two patients were able to taper off monotherapy ASM (\#36 and \#41, age 18 years and 3 years 9 months) with sustained seizure freedom. Seizure freedom was achieved with valproate (VPA) in 4 patients, topiramate (TPM) in 3 patients, and levetiracetam (LEV) in 2 patients, either as monotherapy or in combination with other drugs. Seizure freedom was sustained for 3 to 8 years (median 3.8 years) at the time of inclusion of these patients in the study. Seizure reduction was observed with VPA in 8 patients, LEV in 5, TPM in 5, and lamotrigine in 4 patients. Seizure worsening or side effects causing cessation of drug use was seen with LEV in 3 patients, with VPA and TPM in 2 patients each, and with lacosamide in 1 patient, either as monotherapy or in combination with other drugs.

Six patients tried the ketogenic diet: 2 had a seizure reduction, while the remaining 4 had no effect. Cannabidiol was tried only in 2 patients, without any effect. Vagal nerve stimulation implantation was tried in 3 patients and resulted in seizure freedom in 1 patient and reduced seizure frequency in 2 patients.

\section{Genetics}

Ninety-seven different variants were identified in 142 patients; 38 were previously unpublished. In all cases where inheritance could be determined, variants occurred de novo. Missense variants were present in $24.6 \%$ of the patients, a 3 -AA in-frame deletion was seen in $9.9 \%$, while the remaining $65.5 \%$ carried 
A.a

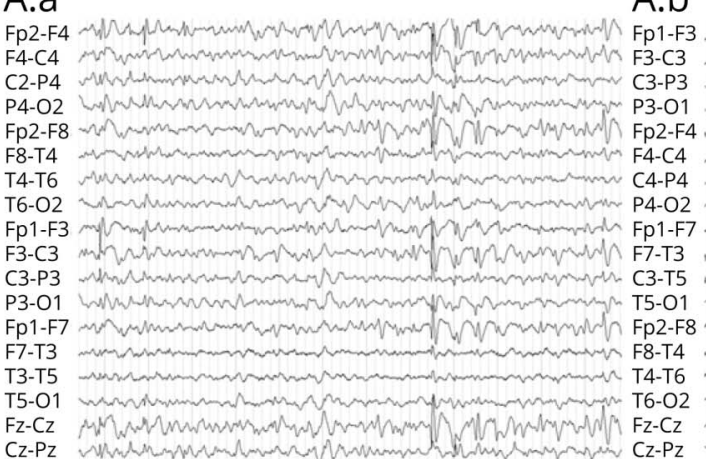

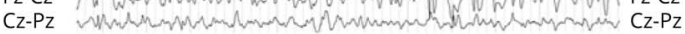

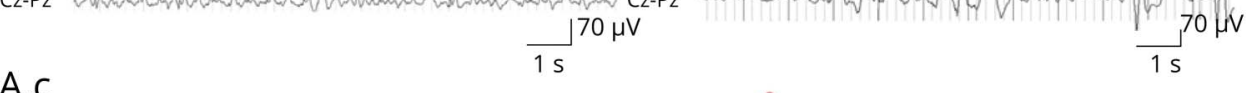

A.C

$1 \mathrm{~s}$

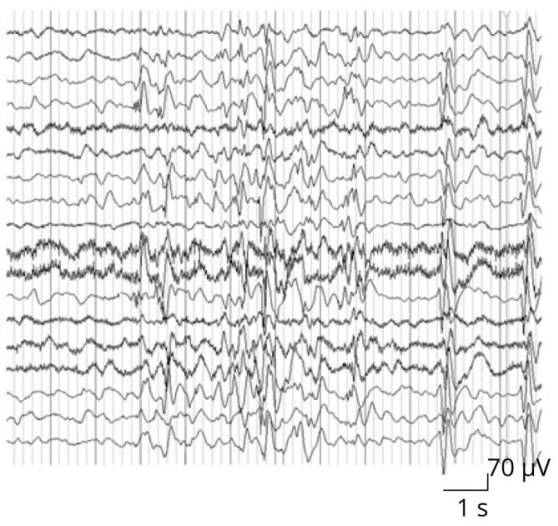

FP2-F4 m C C

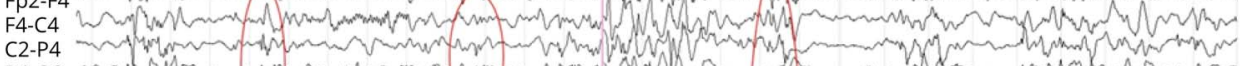

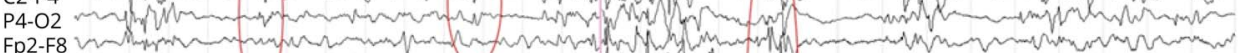
F8-T4 2 -F8

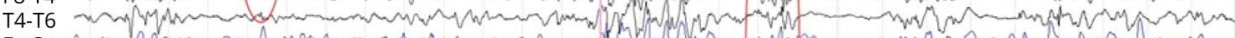
FZ-CZ unn trom

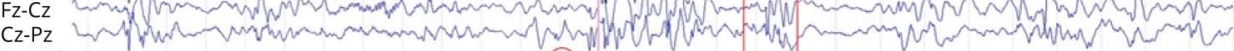

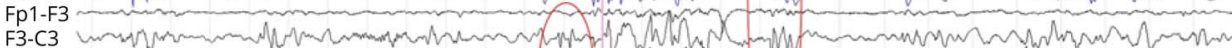
C3-C3 Un L

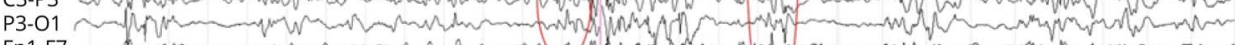

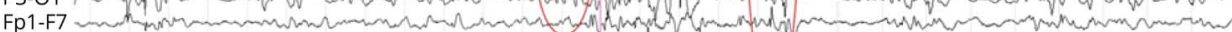
F7-T3 Ln

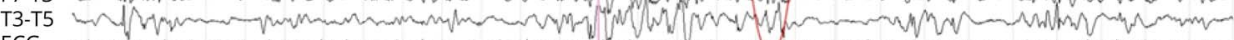

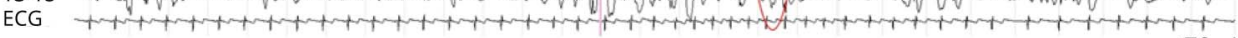
${ }_{1 \mathrm{~s}} 70 \mu$

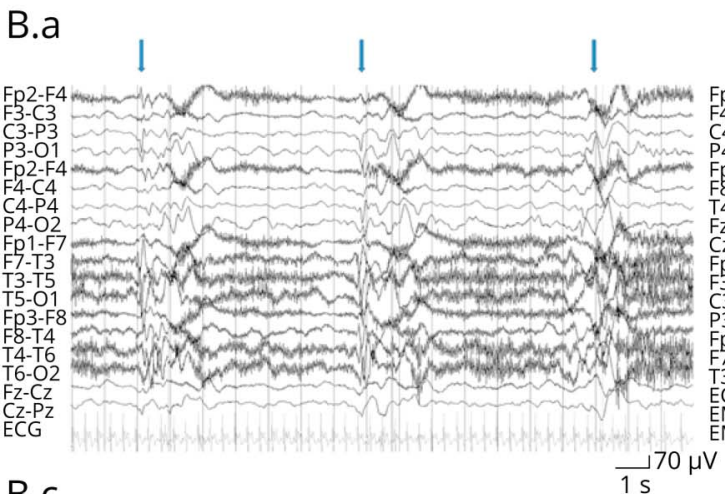

B.b startle induced by acoustic stimulus

B.C $1 \mathrm{~s}$

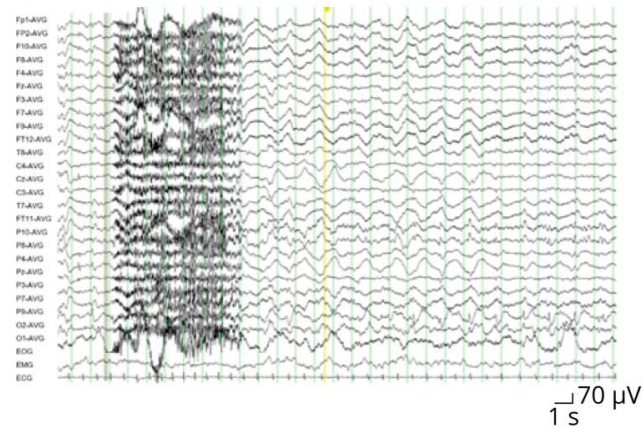

\section{B.}

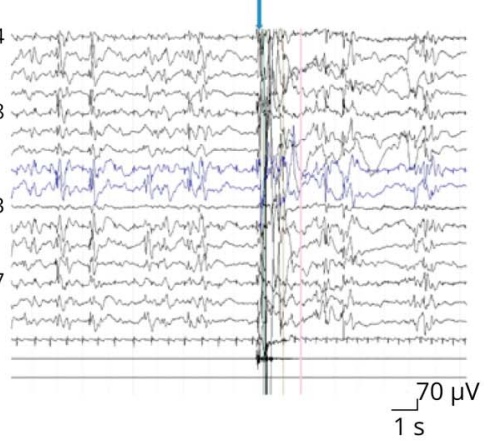

s

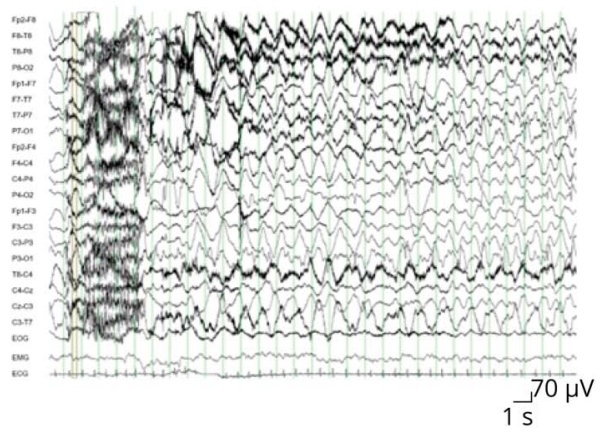

(A) The interictal EEG is characterized by slow background and multifocal spike/sharp and slow waves predominant either in the frontal regions $(a, p t . \# 42)$ or in the posterior quadrants (b, pt. \#30). The epileptiform activity is accentuated during sleep; this image (c, pt. \#19) shows very frequent multifocal spike/polyspikes and waves and sharp and slow waves, in dependently in the right central, right parietal, and left central regions or diffuse. (B) The ictal EEG showed (a) cluster of epileptic spasms (each arrow corresponds to a spasm) (pt. \#30), (b) a startle induced by acoustic stimulus (pt. \#19), and (c) brief tonic seizures out of sleep with an EEG correlation consisting of diffuse rapid activity (3-6 seconds) followed by diffuse delta activity and trains of spike and slow waves in the posterior regions (pt. \#30). PURA = purine-rich element-binding protein $A$. protein-truncating variants (PTVs) such as in-frame deletions, stop-, and frameshift variants. Missense variants and PTVs were seen in patients with similar phenotypes and both with and without epilepsy.
Nineteen variants were seen at the same position-most of them detected only in 2 or 3 patients, but the p.(Leu54Alafs*)/ p. (Leu54Cysfs $\left.{ }^{*}\right)$ was seen in 6 patients, the p. (Val226Glyfs $\left.{ }^{*}\right) /$ p. (Val226Serfs $\left.{ }^{*}\right)$ was seen in 4 patients, the p.(Phe233del) was 
seen in 14 patients, the p. $\left(\operatorname{Arg} 245^{*}\right) / \mathrm{p}$.(Arg245Pro) was seen in 4 patients, and the p.(Phe271del) was also seen in 4 patients (eTable 3, links.lww.com/NXG/A450). Patients both with and without epilepsy were seen in several of these variants, even within the same variant. See eTable 3 for a summary.

The variants were distributed throughout the gene: $33.1 \%$ were located in the PUR-I repeat, $21.8 \%$ in the PUR-II repeat, and $23.2 \%$ in the PUR-III repeat, whereas the remainder were outside the PUR repeats (Figure 3). Five missense variants were located outside the PUR repeats. ${ }^{2,5,7}$

Two patients had compound heterozygous variants (\#62 and \#97); however, their clinical presentation did not vary from the heterozygous variants, ${ }^{5}$ inheritance was either de novo or unknown, and only 1 of the variants in each patient was defined as pathogenic according to the American College of Medical Genetics and Genomics guidelines. ${ }^{16}$

\section{Discussion}

With this comprehensive study of 142 patients, we provide an outline of the phenotypic and genotypic spectrum of the PURA syndrome and we significantly expand the current patient population, suggesting that pathogenic variants in PURA might underlie ID and developmental and epileptic encephalopathy (DEE), more often than previously thought.

This study was done retrospectively and through clinician assessment of patients. When original EEG tracings were not available for review, EEG evaluation was based on EEG reports, discussing them, when necessary, with the referring physician. Unfortunately, longitudinal EEG data were not available; therefore, it has not been possible to evaluate the EEG evolution during the course of the disease.

Some data points are missing in some patients, although follow-up with clinicians was attempted. Patients were also assessed only once for inclusion; thus, longitudinal clinical data were not available in this study.

Most commonly, patients with PURA syndrome present with neonatal hypotonia, complicated by feeding difficulties, often requiring tube feeding, and respiratory distress.

The respiratory distress can be as severe as to cause respiratory insufficiency, requiring frequent recurrent pulmonary aspiration and often demanding mechanical ventilation because of the increased risk of central apnea, similar to the picture reported in patients with 5q31 microdeletions encompassing the PURA gene, who also feature a marked hypotonia at birth. ${ }^{8}$

Hypersomnolence and hypothermia further demonstrate the severity of the PURA syndrome. There were no significant differences between patients with and without neonatal hypotonia at inclusion, neither in the phenotypic appearances nor in the genetics. The hypotonia persists through childhood and adulthood, although in some patients, it gradually improves and motor skills continue to develop, eventually resulting in the acquisition of autonomous walking. This may reflect the steady increase of Pur- $\alpha$ during development, as seen in the mice. ${ }^{3,19}$ The median age at inclusion was 6 years; thus, the estimated numbers are to be considered minimum values. In patients able to ambulate, gait is often ataxic; this finding can correlate with the fact that PURA expression peaks in the postnatal period, when interneuronal connections are being established, especially in the cerebellum. ${ }^{3}$ Gait disturbances were also found in the heterozygous mouse. ${ }^{4}$

Nonepileptic paroxysmal motor manifestations and pathologic startles were reported in a significant proportion of patients, both with and without epilepsy. In recent years, the occurrence of nonepileptic movement disorders in participants with DEE has been increasingly recognized. ${ }^{20,21}$ Indeed, hyperkinetic movement manifestations, such as dystonia and choreoathetosis, are now considered a common phenotypic feature in individuals

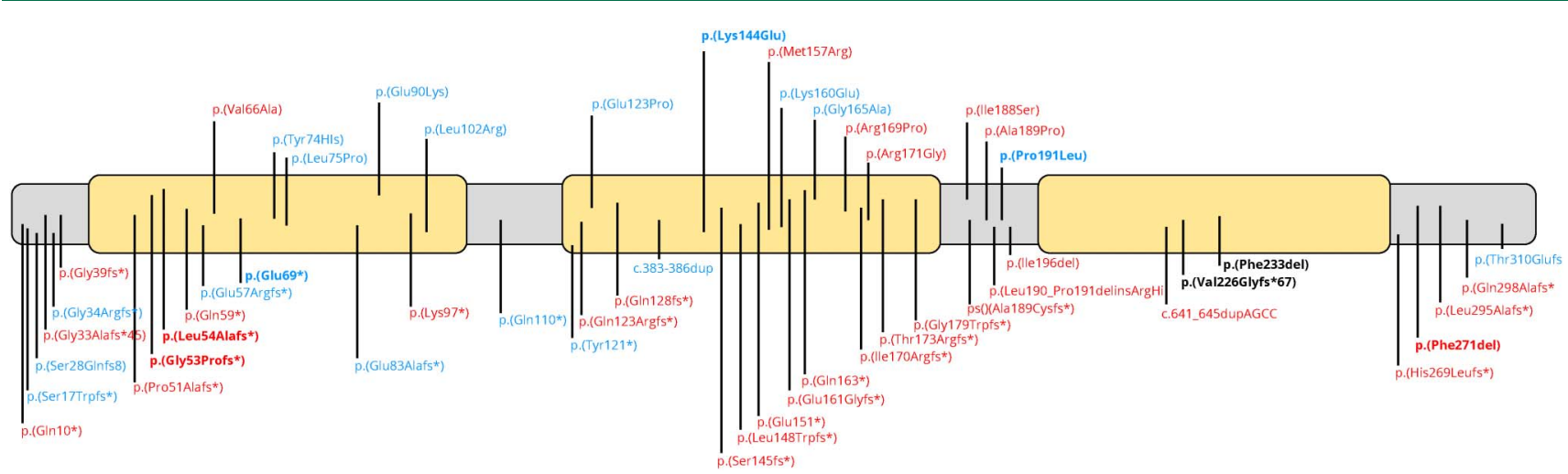

The PURA gene with previously unpublished variants. Missense on top, protein-truncating variants below. With epilepsy in red, without epilepsy in blue, and recurrent variant in bold. PUR repeats indicated by yellow coloring: PUR-I position 42-106, PUR-II position 120-182, and PUR-III position 197-252. PURA= purine-rich element-binding protein A. 
with FOXG1, GNAO1, SCN8A, CACNA1B, and STXBP1-related epilepsy-dyskinesia syndromes. ${ }^{22-26}$ Hand stereotypies are commonly observed in children with autism or developmental delay, irrespective of precise etiology, ${ }^{27}$ and "per se" they do not confer any specificity to affected patients; however, the definition of detailed accompanying phenotypes (such as hyperkinetic movements or hand stereotypies) can be important to characterize the disease spectrum and the early recognition of the PURA-related DEE, ultimately prompting referral of the patients for genetic testing.

A pathologic startle was observed in approximately $18 \%$ of our patients. At variance with our patients, the Pur- $\alpha_{+/-}$mouse shows a trend toward a reduced startle response to acoustic stimuli, a finding considered unexpected by the authors of the study ${ }^{4}$ that requires to be further investigated, while the mouse also displayed occasional seizures on handling. ${ }^{3}$ Exaggerated startle attacks, described as sudden tonic postures with raising of bent arms over the head, flexion of the neck and trunk, in response to touch or sound stimuli, not associated with epileptic changes in the EEG, ${ }^{28}$ have been reported in $38 \%$ of a cohort of children presenting with an encephalopathy associated with KCNQ2 pathogenic variants. ${ }^{29}$ Our findings of a pathologic startle, previously unreported, might add to the constellation of clinical features that could contribute to an early diagnosis of PURA-related DEE.

In older patients, scoliosis is common because of truncal hypotonia. Other features include impaired intestinal motility (reflux and constipation most commonly), visual disturbances, and in a few patients hearing deficits as well. The underlying mechanisms for these features are unknown.

In our study cohort, 3 patients died because of respiratory failure and 1 because of SUDEP. ${ }^{5,7,30}$ PURA knockout (KO) mice do not survive beyond 28 postnatal days ${ }^{3}$; however, an increased death rate is not observed in the heterozygous mice $\left(P U R A_{+/-}\right) .^{3}$ Thus, we can speculate that if the human phenotype is comparable with the heterozygous mouse, the mortality seen in our cohort might be an expression of the increased mortality associated with severe developmental disorders and epilepsy in general and not linked directly to PURA. On the contrary, if the mortality rate observed here is indeed related to PURA-related DEE, it is lower than that reported in Dravet syndrome (15.84/1,000 person-years), ${ }^{31}$ whereas it is comparable with the mortality seen in other DEEs, such as SCN8A-related DEE (mortality 5.3\%), which also shows similar causes of death. ${ }^{32}$ Lack of longitudinal follow-up in this study is a limitation in the assessment of the mortality. Further studies, in particular investigating the natural history of the PURA-related DEE, might be helpful to solve this issue and to establish the mortality rate of this DEE.

MRIs were normal in half of the patients, whereas the other half showed demyelination or loss of brain volume. In 1 patient (\#54), follow-up MRI showed a normalization of myelination over time; therefore, we could speculate that myelination in patients with PURA syndrome is not absent but delayed. Further follow-up MRI data in additional patients will clarify this issue. Experimental studies in $\mathrm{KO}$ mouse have provided conflicting results, showing in some reports decreased signals from myelin and white matter tracts both in the subcortical white matter and in the cortex compared with wild-type littermates and reduced neuron density both in the cortex and in the cerebellum. ${ }^{3}$ Other studies in $\mathrm{KO}$ mice showed an enlarged brain size associated with a phenotype showing ataxia and continuous tremor. ${ }^{33}$ The finding of a megalocephalic brain has been interpreted as resulting from a prolongation of neuronal precursor cell proliferation during postnatal development, an explanation that further supports the role of Pura in postnatal brain development. ${ }^{3}$

In a computational analysis of photographs of 34 PURA syndrome individuals, it was found that affected patients shared a similar gestalt, including a hypotonic face and high anterior hairline. ${ }^{7}$ In addition to those features, we expand the facial gestalt to include a flat nasal bridge with a widened and triangular nasal tip, thickened nostrils, a well-defined philtrum, heavy eyebrows, and periorbital fullness, present in a subset of individuals. Many syndromes have recognizable facial features that are highly informative to clinical geneticists. ${ }^{34-36}$ Although PURA is not an easily recognizable syndrome, a detailed description of dysmorphic features and an understanding of how the features change over time can help clinicians identify further cases.

In total, $59.2 \%$ of the patients analyzed in this study have epilepsy, with age at onset ranging from the first day of life to 18 years. In the heterozygous mouse model, seizures/epilepsy are constant features in all animals. ${ }^{3}$ Most of the patients presented with a combination of seizure types that could be both focal and generalized in the same patient. Our results show that the most common seizure types are myoclonic, GTC, and focal with secondary generalization. A not negligible group of patients presented with reflex seizures whose semiology includes myoclonic, atonic, and "absence-like" manifestations. Various stimulus types (including visual, auditory, sensory, and painful stimulations), were reported as effective in triggering seizures. In some patients, a reflex mechanisms was observed only for a transitory period; therefore, we cannot exclude that the occurrence of reflex seizures in patients with PURA syndrome might be underestimated, particularly in patients with severe ID, high seizure frequency, co-occurrence of nonepileptic paroxysmal motor disorders, and limited monitoring.

The EEG also showed a mixture of focal/multifocal and generalized epileptic abnormalities. Of interest, an excessive activation of EEG epileptic discharges during sleep, resembling an ESES EEG pattern, was reported in 4 children; whether this sleep activation was associated with further cognitive/behavioral deterioration as in ESES syndrome was not possible to demonstrate because of the severity of the baseline cognitive status. Our findings suggest that PURA might add to the growing list of DEE-associated genes that 
can present during the course of the disease with an ESES-like EEG pattern. ${ }^{37,38}$ Hypsarrhythmia and burst suppression were rarely observed. A syndromic classification that considered both the clinical and EEG features was possible only in 6 patients, with 4 of them presenting a clinical picture compatible with a Lennox-Gastaut syndrome and the other 2 with West syndrome. The remaining patients with epilepsy could be broadly diagnosed as presenting with a DEE, in most cases with a severe course.

In total, $40.9 \%$ of patients in our cohort did not present with epilepsy. However, because of the broad age range of epilepsy onset (from the first day of life up to 18 years) and the age at inclusion in this study, only 1 patient without epilepsy was older than 18 years. Thus, we cannot exclude that a proportion of nonepileptic patients will develop epilepsy later in the course of their disease, in particular those nonepileptic patients who already present epileptic abnormalities in their EEG. This hypothesis may be supported by the statistical significant difference in the age at inclusion in our study of the subgroup of patients with epilepsy who were older than the subgroup without epilepsy. The nonepileptic patient older than 18 years was retrieved in the literature, and he was a 19-year-old man who presented with developmental delay since birth; he was able to walk by the age of 4 years and to communicate with a one-two word vocabulary. ${ }^{13} \mathrm{He}$ had a normal MRI and normal EEG (the last one at 14 years of age) ${ }^{13} \mathrm{He}$ carried a de novo recurrent missense variant, p.(Ile188Thr), as well as an Xp22.31 duplication. ${ }^{13}$ In the literature, another patient with the same missense variant also had no seizure activity at the age of 8 years, ${ }^{2}$ whereas a third patient with a frameshift variant at the same position had GTCs with an unknown age at onset. ${ }^{5}$ Thus, at present, an estimation of the prevalence of epilepsy in the PURA population is not reliable because most of the reported patients are children, who could still present with epilepsy at a later age. In line with this, pediatric epilepsy cohort studies have not identified PURA as one of the more common causes of epilepsy in infancy. ${ }^{39}$ However, in a recent study from our center, we identified a pathogenic variant in PURA as the underlying cause of epilepsy in $1 \%$ of adult patients. ${ }^{40}$

Our results show that $66.6 \%$ of the patients with PURA syndrome suffer from drug-refractory epilepsy. Although some ASMs, such as VPA, LEV, and TPM, showed favorable results in some patients, the same drugs were ineffective in other patients, currently making treatment recommendations for patients with PURA syndrome difficult. Further studies elucidating the underlying pathophysiologic mechanisms in PURA-related epilepsy will be crucial, including (heterozygous) animal models to test possible novel drugs and to identify possible precision medicine approaches.

In this study, we expand the genetic landscape of PURA by including 38 new variants. In all patients where segregation analysis was completed, the variants arose de novo. In addition, most of the patients have variants that are loss of function per se, such as frameshift or indel variants. This is supported by a pLoF (predicted loss-of-function) score of 8.9 (pLi 0.94), suggesting that the PURA gene is intolerant to loss of function variants (gnomad.broadinstitute.org/). Thus, haploinsufficiency seems to be the most likely functional defect underlying the disease. Although missense variants have not been tested functionally, the evidence that patients with missense variants display phenotypes similar to the patients with loss of function variants points toward similar functional effects.

Most of the variants were located within the PUR repeats, which underline the importance of these repeats for the function of PURA. ${ }^{41}$ Some variants, both nonsense and missense, are still located outside the PUR repeats, suggesting that these areas of the gene are also crucial for the correct functioning of PURA.

Phenotypic variability was seen even within variants; where the same variant was seen in patients with and without epilepsy. This might reflect other factors, such as epigenetic modulators, or it might be simply due to a difference in age of the patients (see above).

Previously, a single patient with a variant in the C-terminal of the protein was described with a milder phenotype compared with other patients, which led the authors to suggest that it is unlikely for variants in the far end of the $\mathrm{C}$-terminal to affect protein folding or nucleic acid binding. ${ }^{7}$ However, our results do not support this hypothesis because also patients with variants in this part of the gene (such as \#42) seem to display an equally severe PURA phenotype. There were also no apparent differences between variants in the $5^{\prime}$ and $3^{\prime}$ end of the protein. No clear genotypephenotype associations emerged from the analysis of our cohort.

Our study further defines and expands the phenotypic and genotypic spectrum of the PURA-related DEE. Some clinical features, especially in the neonatal age, including hypotonia, feeding, and respiratory difficulties, are characteristic and should raise the suspicion of PURA, prompting genetic screening. In our cohort, more than $60 \%$ of patients have epilepsy, characterized by a very wide range of age at onset, from the neonatal period up to early adulthood; therefore, it cannot be excluded that a further fraction of patients, still in their childhood and not presenting epilepsy yet, will develop epilepsy later in their disease course. The epilepsy featured a wide spectrum of seizure types, including both focal, generalized seizures, and reflex seizures, refractory to currently available ASMs in the great majority of patients. Finally, our study failed to identify genotypephenotype associations. Additional studies investigating the functions of PURA and the pathophysiologic mechanism underlying the PURA-related DEE are needed to guide the search for more effective and possibly targeted treatments.

\section{Acknowledgment}

The authors are deeply grateful for the collaboration and support from all the PURA families, and the authors wish to acknowledge the PURA foundation for their tireless work and commitment to advance the knowledge on PURA syndrome. 
The authors thank Diana Baralle for inclusion of patients and Dierk Niessing and Robert Janowski for their invaluable support and comments on the manuscript. The authors thank the following for their contributions to the study: Deborah Mitchell-Langlois. The authors thank Jean-François Deleuze, Anne Boland-Augé, and Robert Olaso for the collaboration CEA/JACOB/CNRGH_CHU de Dijon-Inserm.

\section{Study Funding}

The open access for this paper was funded by the PURA Syndrome Foundation. J. Buratti received research funding as a site investigator from Alexion, AveXis, Biogen, CSL Behring, Cytokinetics, Fibrogen, Pfizer, PTC Therapeutics, Sarepta, Summit, and WaVe. I. Helbig was supported by The Hartwell Foundation through an Individual Biomedical Research Award. This work was also supported by the National Institute for Neurological Disorders and Stroke (K02 NS112600), including support through the Center Without Walls on ion channel function in epilepsy ("Channelopathyassociated Research Center”, U54 NS108874), the Eunice Kennedy Shriver National Institute of Child Health and Human Development through the Intellectual and Developmental Disabilities Research Center (IDDRC) at Children's Hospital of Philadelphia and the University of Pennsylvania (U54 HD086984), and by intramural funds of the Children's Hospital of Philadelphia through the Epilepsy NeuroGenetics Initiative (ENGIN). Research reported in this publication was also supported by the National Center for Advancing Translational Sciences of the NIH under Award Number UL1TR001878. The content is solely the responsibility of the authors and does not necessarily represent the official views of the NIH. This project was also supported in part by the Institute for Translational Medicine and Therapeutics' (ITMAT) Transdisciplinary Program in Translational Medicine and Therapeutics at the Perelman School of Medicine of the University of Pennsylvania. The study also received support through the EuroEPINOMICSRare Epilepsy Syndrome (RES) Consortium, which provided the capacity for exome sequencing, by the German Research Foundation (HE5415/3-1 to I. Helbig) within the EuroEPINOMICS framework of the European Science Foundation, by the German Research Foundation (DFG; HE5415/51 and HE5415/6-1 to I. Helbig), by the DFG Research Unit FOR2715 (He5415/7-1 to I. Helbig), and by the Genomics Research and Innovation Network (GRIN, grinnetwork.org). I. Helbig also received support through the International League Against Epilepsy.

\section{Disclosure}

J. Buratti has worked as a consultant for Alexion, Audentes, AveXis, Biogen, Cytokinetics, Genentech, Momenta, PTC Therapeutics, Sarepta, and WaVe. The other authors report no disclosures. Go to Neurology.org/NG for full disclosures.

\section{Publication History}

Received by Neurology: Genetics November 3, 2020. Accepted in final form June 29, 2021.

\section{Appendix Authors}

\begin{tabular}{|c|c|c|}
\hline Name & Location & Contribution \\
\hline $\begin{array}{l}\text { Katrine M. } \\
\text { Johannesen, } \\
\text { MD, PhD }\end{array}$ & $\begin{array}{l}\text { Department of Epilepsy } \\
\text { Genetics and Personalized } \\
\text { Treatment, The Danish } \\
\text { Epilepsy Centre Filadelfia, } \\
\text { Dianalund, Denmark } \\
\text { Institute for Regional Health } \\
\text { Research, University of } \\
\text { Southern Denmark, } \\
\text { Odense, Denmark }\end{array}$ & $\begin{array}{l}\text { Drafting/revision of the } \\
\text { manuscript for content, } \\
\text { including medical writing for } \\
\text { content; Major role in the } \\
\text { acquisition of data; Study } \\
\text { concept or design; Analysis } \\
\text { or interpretation of data }\end{array}$ \\
\hline $\begin{array}{l}\text { Elena } \\
\text { Gardella, MD, } \\
\text { PhD }\end{array}$ & $\begin{array}{l}\text { Department of Epilepsy } \\
\text { Genetics and Personalized } \\
\text { Treatment, The Danish } \\
\text { Epilepsy Centre Filadelfia, } \\
\text { Dianalund, Denmark } \\
\text { Institute for Regional Health } \\
\text { Research, University of } \\
\text { Southern Denmark, } \\
\text { Odense, Denmark }\end{array}$ & $\begin{array}{l}\text { Major role in the acquisition } \\
\text { of data; Analysis or } \\
\text { interpretation of data }\end{array}$ \\
\hline
\end{tabular}

\begin{tabular}{lll}
\hline Cathrine E. & Department of Epilepsy & Major role in the acquisition \\
Gjerulfsen, & Genetics and Personalized & of data \\
MD & Treatment, The Danish \\
& Epilepsy Centre Filadelfia, \\
& Dianalund, Denmark \\
Institute for Regional Health & \\
& Research, University of \\
& Southern Denmark, \\
& Odense, Denmark
\end{tabular}

\begin{tabular}{|c|c|c|}
\hline $\begin{array}{l}\text { Allan Bayat, } \\
\text { MD }\end{array}$ & $\begin{array}{l}\text { Department of Epilepsy } \\
\text { Genetics and Personalized } \\
\text { Treatment, The Danish } \\
\text { Epilepsy Centre Filadelfia, } \\
\text { Dianalund, Denmark }\end{array}$ & $\begin{array}{l}\text { Drafting/revision of the } \\
\text { manuscript for content, } \\
\text { including medical writing for } \\
\text { content }\end{array}$ \\
\hline
\end{tabular}

\begin{tabular}{lll}
\hline Rob P.W. & $\begin{array}{l}\text { Department of Neurology, } \\
\text { Rouhl, MD } \\
\text { Maastricht University } \\
\text { Medical Centre (MUMC+), } \\
\text { Maastricht, Netherlands } \\
\text { Academic Centre for } \\
\text { Epileptology }\end{array}$ & $\begin{array}{l}\text { Drafting/revision of the } \\
\text { manuscript for content, } \\
\text { including medical writing for } \\
\text { Kempenhaeghe/MUMC+, } \\
\text { content; Major role in the } \\
\text { acquisition of data }\end{array}$ \\
& \\
Maastricht, Netherlands & \\
School for Mental Health & \\
and Neuroscience, & \\
& Maastricht University, \\
& Maastricht, the Netherlands
\end{tabular}

\begin{tabular}{lll}
\hline Margot & Department of Clinical & Major role in the acquisition \\
Reijnders, MD & $\begin{array}{l}\text { Genetics, Maastricht } \\
\text { University Medical Center, } \\
\text { Maastricht, the Netherlands }\end{array}$ \\
\hline
\end{tabular}

\begin{tabular}{lll}
\hline Sandra & APHP.Sorbonne Université, & Major role in the acquisition \\
Whalen, MD & Hôpital Armand Trousseau, of data \\
& UF de Génétique Clinique, \\
& Centre de Référence \\
& Anomalies du Développement \\
& et Syndromes Malformatifs, \\
& Paris, France
\end{tabular}

\begin{tabular}{lll}
\hline Boris Keren, & Department of Genetics, & Major role in the acquisition \\
MD, PhD & $\begin{array}{l}\text { Pitié-Salpêtrière hospital, } \\
\text { APHP, Sorbonne Université, }\end{array}$ & \\
& Paris, France
\end{tabular}

\begin{tabular}{lll}
\hline $\begin{array}{l}\text { Julien } \\
\text { Buratti, MSc }\end{array}$ & $\begin{array}{l}\text { Department of Genetics, } \\
\text { Pitié-Salpêtrière hospital, } \\
\text { APHP, Sorbonne Université, } \\
\text { Paris, France }\end{array}$ & $\begin{array}{l}\text { Major role in the acquisition } \\
\text { of data }\end{array}$ \\
\hline Thomas & $\begin{array}{l}\text { Department of Genetics, } \\
\text { Courtin, MD }\end{array}$ & $\begin{array}{l}\text { Pitié-Salpêtrière hospital, role in the acquisition } \\
\text { APHP, Sorbonne Université, } \\
\text { Paris, France }\end{array}$ \\
\hline
\end{tabular}


Appendix (continued)

\begin{tabular}{|c|c|c|}
\hline Name & Location & Contribution \\
\hline $\begin{array}{l}\text { Klaas J. } \\
\text { Wierenga, } \\
\text { MD }\end{array}$ & $\begin{array}{l}\text { Department of Clinical } \\
\text { Genomics, Mayo Clinic } \\
\text { Florida, Jacksonville }\end{array}$ & $\begin{array}{l}\text { Major role in the acquisition } \\
\text { of data }\end{array}$ \\
\hline $\begin{array}{l}\text { Bertrand } \\
\text { Isidor, MD }\end{array}$ & $\begin{array}{l}\text { Service de Génétique } \\
\text { Médicale, CHU de Nantes, } \\
\text { France }\end{array}$ & $\begin{array}{l}\text { Major role in the acquisition } \\
\text { of data }\end{array}$ \\
\hline $\begin{array}{l}\text { Amélie Piton, } \\
\text { MD }\end{array}$ & $\begin{array}{l}\text { Service de Génétique } \\
\text { Médicale, CHU de Nantes, } \\
\text { France }\end{array}$ & $\begin{array}{l}\text { Major role in the acquisition } \\
\text { of data }\end{array}$ \\
\hline $\begin{array}{l}\text { Laurence } \\
\text { Faivre, MD }\end{array}$ & $\begin{array}{l}\text { Centre de Référence } \\
\text { Anomalies du } \\
\text { Développement et } \\
\text { Syndromes Malformatifs, } \\
\text { FHU TRANSLAD, CHU Dijon, } \\
\text { Dijon, France; INSERM } \\
\text { UMR1231, GAD team, } \\
\text { Université de Bourgogne- } \\
\text { Franche Comté, Dijon, } \\
\text { France }\end{array}$ & $\begin{array}{l}\text { Major role in the acquisition } \\
\text { of data }\end{array}$ \\
\hline $\begin{array}{l}\text { Aurore } \\
\text { Garde, MD }\end{array}$ & $\begin{array}{l}\text { Centre de Référence } \\
\text { Anomalies du } \\
\text { Développement et } \\
\text { Syndromes Malformatifs, } \\
\text { FHU TRANSLAD, CHU Dijon, } \\
\text { Dijon, France; INSERM } \\
\text { UMR1231, GAD team, } \\
\text { Université de Bourgogne- } \\
\text { Franche Comté, Dijon, } \\
\text { France }\end{array}$ & $\begin{array}{l}\text { Major role in the acquisition } \\
\text { of data }\end{array}$ \\
\hline $\begin{array}{l}\text { Sébastien } \\
\text { Moutton, MD }\end{array}$ & $\begin{array}{l}\text { Centre de Référence } \\
\text { Anomalies du } \\
\text { Développement et } \\
\text { Syndromes Malformatifs, } \\
\text { FHU TRANSLAD, CHU Dijon, } \\
\text { Dijon, France; INSERM } \\
\text { UMR1231, GAD team, } \\
\text { Université de Bourgogne- } \\
\text { Franche Comté, Dijon, } \\
\text { France }\end{array}$ & $\begin{array}{l}\text { Major role in the acquisition } \\
\text { of data }\end{array}$ \\
\hline $\begin{array}{l}\text { Frédéric } \\
\text { Tran-Mau- } \\
\text { Them, MD }\end{array}$ & $\begin{array}{l}\text { INSERM UMR1231, GAD } \\
\text { team, Université de } \\
\text { Bourgogne-Franche } \\
\text { Comté, Dijon, France; } \\
\text { Unité Fonctionnelle } \\
\text { dlnnovation diagnostique } \\
\text { des maladies rares, Pôle de } \\
\text { Biologie, FHU-TRANSLAD, } \\
\text { CHU Dijon Bourgogne, } \\
\text { Dijon, France }\end{array}$ & $\begin{array}{l}\text { Major role in the acquisition } \\
\text { of data }\end{array}$ \\
\hline $\begin{array}{l}\text { Anne-Sophie } \\
\text { Denommé- } \\
\text { Pichon, MD }\end{array}$ & $\begin{array}{l}\text { Service de Génétique } \\
\text { Médicale, CHU de Nantes, } \\
\text { France }\end{array}$ & Study concept or design \\
\hline $\begin{array}{l}\text { Christine } \\
\text { Coubes, MD }\end{array}$ & $\begin{array}{l}\text { Department of Medical } \\
\text { Genetics, Rare Diseases and } \\
\text { Personalized Medicine, CHU } \\
\text { Montpellier, Montpellier, } \\
\text { France }\end{array}$ & $\begin{array}{l}\text { Major role in the acquisition } \\
\text { of data }\end{array}$ \\
\hline $\begin{array}{l}\text { Austin } \\
\text { Larson, MD }\end{array}$ & $\begin{array}{l}\text { Childrens Hospital } \\
\text { Colorado, Anschutz Medical } \\
\text { Campus, Aurora, CO }\end{array}$ & $\begin{array}{l}\text { Major role in the acquisition } \\
\text { of data }\end{array}$ \\
\hline $\begin{array}{l}\text { Michael J. } \\
\text { Esser, MD }\end{array}$ & $\begin{array}{l}\text { Division of Clinical } \\
\text { Neuroscience, } \\
\text { Department of Pediatrics, } \\
\text { Alberta, Canada }\end{array}$ & $\begin{array}{l}\text { Major role in the acquisition } \\
\text { of data }\end{array}$ \\
\hline
\end{tabular}

Appendix (continued)

\begin{tabular}{|c|c|c|}
\hline Name & Location & Contribution \\
\hline $\begin{array}{l}\text { Juan Pablo } \\
\text { Appendino, } \\
\text { MD }\end{array}$ & $\begin{array}{l}\text { Division of Clinical } \\
\text { Neuroscience, Department of } \\
\text { Pediatrics, Alberta, Canada; } \\
\text { Alberta Childrens Hospital, } \\
\text { Cumming School of Medicine, } \\
\text { University of Calgary, Calgary, } \\
\text { Alberta, Canada }\end{array}$ & $\begin{array}{l}\text { Major role in the acquisition } \\
\text { of data }\end{array}$ \\
\hline $\begin{array}{l}\text { Walla Al- } \\
\text { Hertani, MD }\end{array}$ & $\begin{array}{l}\text { Department of Pediatrics, } \\
\text { Division of Genetics and } \\
\text { Genomics, Boston Childrens } \\
\text { Hospital and Harvard } \\
\text { Medical School, Boston, MA }\end{array}$ & $\begin{array}{l}\text { Major role in the acquisition } \\
\text { of data }\end{array}$ \\
\hline $\begin{array}{l}\text { Beatriz } \\
\text { Gamboni, MD }\end{array}$ & $\begin{array}{l}\text { Instituto de Neurología } \\
\text { Infanto Juvenil, Neuroinfan, } \\
\text { Mendoza, Argentina }\end{array}$ & $\begin{array}{l}\text { Major role in the acquisition } \\
\text { of data }\end{array}$ \\
\hline $\begin{array}{l}\text { Alejandra } \\
\text { Mampel, MD }\end{array}$ & $\begin{array}{l}\text { Instituto de Genetica- } \\
\text { Hospital Universitario, } \\
\text { Universidad Nacional } \\
\text { de Cuyo, Mendoza, } \\
\text { Argentina }\end{array}$ & $\begin{array}{l}\text { Major role in the acquisition } \\
\text { of data }\end{array}$ \\
\hline $\begin{array}{l}\text { Lía Mayorga, } \\
\text { MD, PhD }\end{array}$ & $\begin{array}{l}\text { Instituto de Histología y } \\
\text { Embriología de Mendoza } \\
\text { (IHEM), Universidad } \\
\text { Nacional de Cuyo, Mendoza, } \\
\text { Argentina }\end{array}$ & $\begin{array}{l}\text { Major role in the acquisition } \\
\text { of data }\end{array}$ \\
\hline
\end{tabular}

Alessandro Azienda Ospedaliera Major role in the acquisition

Orsini, MD, Universitaria Pisana, Pisa, Italy of data

PhD

\begin{tabular}{lll}
\hline $\begin{array}{l}\text { Alice } \\
\text { Bonuccelli, } \\
\text { MD }\end{array}$ & $\begin{array}{l}\text { Neuropaediatric Section, } \\
\text { Pediatric Department, Santa } \\
\text { Chiara University Hospital, } \\
\text { Pisa, Italy }\end{array}$ & $\begin{array}{l}\text { Major role in the acquisition } \\
\text { of data }\end{array}$ \\
\hline $\begin{array}{l}\text { Agnese } \\
\text { Suppiej, MD }\end{array}$ & $\begin{array}{l}\text { Department of Medical } \\
\text { Sciences- Pediatric Section, } \\
\text { University of Ferrara, } \\
\text { Ferrara, Italy }\end{array}$ & $\begin{array}{l}\text { Major role in the acquisition } \\
\text { of data }\end{array}$ \\
\hline
\end{tabular}

Julien Van- CHU Bordeaux, Bordeaux, Major role in the acquisition

Gils, MD France of data

Julie Vogt, MD West Midlands Regional Major role in the acquisition Genetics Service, of data

Birmingham Women's and

Children's Hospital, Birmingham, UK

\begin{tabular}{|c|c|c|}
\hline $\begin{array}{l}\text { Simona } \\
\text { Damioli, MD }\end{array}$ & $\begin{array}{l}\text { Child Neuropsychiatric } \\
\text { Division, Spedali Civili, } \\
\text { Brescia, Italy }\end{array}$ & $\begin{array}{l}\text { Major role in the acquisition } \\
\text { of data }\end{array}$ \\
\hline $\begin{array}{l}\text { Lucio } \\
\text { Giordano, MD }\end{array}$ & $\begin{array}{l}\text { Child Neuropsychiatric } \\
\text { Division, Spedali Civili, } \\
\text { Brescia, Italy }\end{array}$ & $\begin{array}{l}\text { Major role in the acquisition } \\
\text { of data }\end{array}$ \\
\hline $\begin{array}{l}\text { Stephanie } \\
\text { Moortgat, } \\
\text { MD, PhD }\end{array}$ & $\begin{array}{l}\text { Institut de Pathologie et de } \\
\text { Génétique (IPG), Gosselies, } \\
\text { Belgium }\end{array}$ & $\begin{array}{l}\text { Major role in the acquisition } \\
\text { of data }\end{array}$ \\
\hline $\begin{array}{l}\text { Elaine } \\
\text { Wirrell, MD }\end{array}$ & $\begin{array}{l}\text { Divisions of Child and } \\
\text { Adolescent Neurology and } \\
\text { Epilepsy, Department of } \\
\text { Neurology, Mayo Clinic, } \\
\text { Rochester, MN }\end{array}$ & $\begin{array}{l}\text { Major role in the acquisition } \\
\text { of data }\end{array}$ \\
\hline $\begin{array}{l}\text { Sarah Hicks, } \\
\text { MD }\end{array}$ & $\begin{array}{l}\text { Oxford Centre for Genomic } \\
\text { Medicine, Oxford, United } \\
\text { Kingdom }\end{array}$ & $\begin{array}{l}\text { Major role in the acquisition } \\
\text { of data }\end{array}$ \\
\hline
\end{tabular}

Continued 
Appendix (continued)

\begin{tabular}{|c|c|c|}
\hline Name & Location & Contribution \\
\hline Usha Kini, MD & $\begin{array}{l}\text { Oxford University Hospitals } \\
\text { NHS Trust, Oxford, United } \\
\text { Kingdom }\end{array}$ & $\begin{array}{l}\text { Major role in the acquisition } \\
\text { of data }\end{array}$ \\
\hline $\begin{array}{l}\text { Nathan } \\
\text { Noble, Do }\end{array}$ & $\begin{array}{l}\text { Blank Children's } \\
\text { Developmental Center, } \\
\text { Unity Point Health, West Des } \\
\text { Moines, IA }\end{array}$ & $\begin{array}{l}\text { Major role in the acquisition } \\
\text { of data }\end{array}$ \\
\hline $\begin{array}{l}\text { Helen } \\
\text { Stewart, MD }\end{array}$ & $\begin{array}{l}\text { Oxford Centre for Genomic } \\
\text { Medicine, Oxford, United } \\
\text { Kingdom }\end{array}$ & $\begin{array}{l}\text { Major role in the acquisition } \\
\text { of data }\end{array}$ \\
\hline $\begin{array}{l}\text { Shailesh } \\
\text { Asakar, MD }\end{array}$ & $\begin{array}{l}\text { Sutter Medical Centre, } \\
\text { Sacramento, CA }\end{array}$ & $\begin{array}{l}\text { Major role in the acquisition } \\
\text { of data }\end{array}$ \\
\hline $\begin{array}{l}\text { Julie S. Cohen, } \\
\text { MD }\end{array}$ & $\begin{array}{l}\text { Kennedy Krieger Institute, } \\
\text { Baltimore, MD }\end{array}$ & $\begin{array}{l}\text { Major role in the acquisition } \\
\text { of data }\end{array}$ \\
\hline $\begin{array}{l}\text { SakkuBai R. } \\
\text { Naidu, MD }\end{array}$ & $\begin{array}{l}\text { Johns Hopkins University, } \\
\text { Baltimore, MD }\end{array}$ & $\begin{array}{l}\text { Major role in the acquisition } \\
\text { of data }\end{array}$ \\
\hline $\begin{array}{l}\text { Ashley } \\
\text { Collier, MD }\end{array}$ & $\begin{array}{l}\text { Provincial Medical Genetics } \\
\text { Program, St. Johns Medical } \\
\text { Center, NL, Canada }\end{array}$ & $\begin{array}{l}\text { Major role in the acquisition } \\
\text { of data }\end{array}$ \\
\hline $\begin{array}{l}\text { Eva H. } \\
\text { Brilstra, MD }\end{array}$ & $\begin{array}{l}\text { University Medical Center } \\
\text { Utrecht, Utrecht, the } \\
\text { Netherlands }\end{array}$ & $\begin{array}{l}\text { Major role in the acquisition } \\
\text { of data }\end{array}$ \\
\hline $\begin{array}{l}\text { Mindy H. Li, } \\
\text { MD }\end{array}$ & $\begin{array}{l}\text { Rush University Medical } \\
\text { Center, Chicago, IL }\end{array}$ & $\begin{array}{l}\text { Major role in the acquisition } \\
\text { of data }\end{array}$ \\
\hline $\begin{array}{l}\text { Casey Brew, } \\
\text { MD }\end{array}$ & $\begin{array}{l}\text { Rush University Medical } \\
\text { Center, Chicago, IL }\end{array}$ & $\begin{array}{l}\text { Major role in the acquisition } \\
\text { of data }\end{array}$ \\
\hline $\begin{array}{l}\text { Stefania } \\
\text { Bigoni, MD }\end{array}$ & $\begin{array}{l}\text { Medical Genetic Unit, } \\
\text { Maternal and Child Dept, } \\
\text { Ferrara University Hospital, } \\
\text { Ferrara, Italy }\end{array}$ & $\begin{array}{l}\text { Major role in the acquisition } \\
\text { of data }\end{array}$ \\
\hline $\begin{array}{l}\text { Davide } \\
\text { Ognibene, } \\
\text { MD }\end{array}$ & $\begin{array}{l}\text { Medical Genetic Unit, } \\
\text { Maternal and Child Dept, } \\
\text { Ferrara University Hospital, } \\
\text { Ferrara, Italy; Medical } \\
\text { Science Dept, Ferrara } \\
\text { University, Italy }\end{array}$ & $\begin{array}{l}\text { Major role in the acquisition } \\
\text { of data }\end{array}$ \\
\hline $\begin{array}{l}\text { Elisa } \\
\text { Ballardini, } \\
\text { MD }\end{array}$ & $\begin{array}{l}\text { Neonatal Intensive Care } \\
\text { Unit, Pediatric Section, } \\
\text { Department of Medical } \\
\text { Sciences, Ferrara University, } \\
\text { Ferrara, Italy }\end{array}$ & $\begin{array}{l}\text { Major role in the acquisition } \\
\text { of data }\end{array}$ \\
\hline $\begin{array}{l}\text { Claudia } \\
\text { Ruivenkamp, } \\
\text { MD }\end{array}$ & $\begin{array}{l}\text { Department of Clinical } \\
\text { Genetics, LUMC, Leiden, } \\
\text { the Netherlands }\end{array}$ & $\begin{array}{l}\text { Major role in the acquisition } \\
\text { of data }\end{array}$ \\
\hline $\begin{array}{l}\text { Raffaella } \\
\text { Faggioli, MD }\end{array}$ & $\begin{array}{l}\text { Pediatric Unit, Maternal and } \\
\text { Child Dept, Ferrara } \\
\text { University Hospital, Ferrara, } \\
\text { Italy }\end{array}$ & $\begin{array}{l}\text { Major role in the acquisition } \\
\text { of data }\end{array}$ \\
\hline $\begin{array}{l}\text { Alexandra } \\
\text { Afenjar, MD }\end{array}$ & $\begin{array}{l}\text { APHP Trousseau, Paris, } \\
\text { France }\end{array}$ & $\begin{array}{l}\text { Major role in the acquisition } \\
\text { of data }\end{array}$ \\
\hline $\begin{array}{l}\text { Diana } \\
\text { Rodriguez, } \\
\text { MD }\end{array}$ & $\begin{array}{l}\text { Service de Neuropédiatrie, } \\
\text { Hopital Trousseau, } \\
\text { Sorbonne Université, } \\
\text { APHP.SU, Paris, France }\end{array}$ & $\begin{array}{l}\text { Major role in the acquisition } \\
\text { of data }\end{array}$ \\
\hline $\begin{array}{l}\text { David Bick, } \\
\text { MD }\end{array}$ & $\begin{array}{l}\text { HudsonAlpha Institute for } \\
\text { Biotechnology, Huntsville, } \\
\text { AL }\end{array}$ & $\begin{array}{l}\text { Major role in the acquisition } \\
\text { of data }\end{array}$ \\
\hline
\end{tabular}

Appendix (continued)

\begin{tabular}{|c|c|c|}
\hline Name & Location & Contribution \\
\hline $\begin{array}{l}\text { Devorah } \\
\text { Segal, MD, } \\
\text { PhD }\end{array}$ & $\begin{array}{l}\text { Department of Pediatrics, } \\
\text { Weill Cornell Medicine, New } \\
\text { York, NY }\end{array}$ & $\begin{array}{l}\text { Major role in the acquisition } \\
\text { of data }\end{array}$ \\
\hline $\begin{array}{l}\text { David Coman, } \\
\text { MD }\end{array}$ & $\begin{array}{l}\text { Queensland Children's } \\
\text { Hospital, Brisbane, QL, } \\
\text { Australia }\end{array}$ & $\begin{array}{l}\text { Major role in the acquisition } \\
\text { of data }\end{array}$ \\
\hline $\begin{array}{l}\text { Boudewijn } \\
\text { Gunning, MD }\end{array}$ & $\begin{array}{l}\text { Department of Neurology, } \\
\text { Stichting Epilepsie } \\
\text { Instellingen Nederland, } \\
\text { Zwolle, the Netherlands }\end{array}$ & $\begin{array}{l}\text { Major role in the acquisition } \\
\text { of data }\end{array}$ \\
\hline $\begin{array}{l}\text { Orrin } \\
\text { Devinsky, MD }\end{array}$ & $\begin{array}{l}\text { Department of Neurology, } \\
\text { NYU School of Medicine, } \\
\text { New York, NY }\end{array}$ & $\begin{array}{l}\text { Major role in the acquisition } \\
\text { of data }\end{array}$ \\
\hline $\begin{array}{l}\text { Laurie A. } \\
\text { Demmer, MD }\end{array}$ & $\begin{array}{l}\text { Atrium Healths Levine } \\
\text { Childrens Hospital, } \\
\text { Charlotte, NC }\end{array}$ & $\begin{array}{l}\text { Major role in the acquisition } \\
\text { of data }\end{array}$ \\
\hline $\begin{array}{l}\text { Theresa } \\
\text { Grebe, MD }\end{array}$ & $\begin{array}{l}\text { Phoenix Childrens Hospital, } \\
\text { Phoenix, United States and } \\
\text { The University of Arizona } \\
\text { College of Medicine }\end{array}$ & $\begin{array}{l}\text { Major role in the acquisition } \\
\text { of data }\end{array}$ \\
\hline $\begin{array}{l}\text { Dario Pruna, } \\
\text { MD }\end{array}$ & $\begin{array}{l}\text { Division of Child Neurology } \\
\text { and Psychiatry, Azienda } \\
\text { Ospedaliero Universitaria, } \\
\text { Cagilari, Italy }\end{array}$ & $\begin{array}{l}\text { Major role in the acquisition } \\
\text { of data }\end{array}$ \\
\hline
\end{tabular}

Ida Cursio, Neurology and Epileptology Major role in the acquisition MD Unit, Pediatric Department, of data Brotzu Hospital Trust, Cagliari, Italy

\begin{tabular}{lll}
\hline $\begin{array}{l}\text { Lynn } \\
\text { Greenhalgh, } \\
\text { MD, MSc }\end{array}$ & $\begin{array}{l}\text { Liverpool Centre for } \\
\text { Genomic Medicine, } \\
\text { Liverpool Womens NHS } \\
\text { Foundation Trust, Liverpool, } \\
\text { United Kingdom }\end{array}$ & $\begin{array}{l}\text { Major role in the acquisition } \\
\text { of data }\end{array}$ \\
\hline $\begin{array}{l}\text { Claudio } \\
\text { Graziano, } \\
\text { MD, PhD }\end{array}$ & $\begin{array}{l}\text { U.O. Genetica Medica, } \\
\text { Policlinico S. Orsola- }\end{array}$ & $\begin{array}{l}\text { Major role in the acquisition } \\
\text { of data }\end{array}$ \\
\hline $\begin{array}{l}\text { Mahulpighi, Bologna, Italy } \\
\text { Singh, MD }\end{array}$ & $\begin{array}{l}\text { Department of Children's } \\
\text { neurosciences, Guys and ST. }\end{array}$ & $\begin{array}{l}\text { Major role in the acquisition } \\
\text { of data }\end{array}$ \\
& $\begin{array}{l}\text { Thomas' NHS foundation } \\
\text { trust, London United }\end{array}$ & \\
& Kingdom
\end{tabular}

\begin{tabular}{lll}
\hline Gaetano & Department of Child & Major role in the acquisition \\
Cantalupo, & $\begin{array}{l}\text { Neuropsychiatry, University } \\
\text { of Verona, Italy }\end{array}$ & \\
MD & of data
\end{tabular}
MD of Verona, Italy

Marjolaine Department of Medical Major role in the acquisition Willems, MD Genetics, Rare Diseases and of data Personalized Medicine, $\mathrm{CHU}$ Montpellier, Montpellier, France

\begin{tabular}{lll}
\hline $\begin{array}{l}\text { Sangeetha } \\
\text { Yoganathan, } \\
\text { MD }\end{array}$ & $\begin{array}{l}\text { Christian Medical College, } \\
\text { Vellore, India }\end{array}$ & $\begin{array}{l}\text { Major role in the acquisition } \\
\text { of data }\end{array}$ \\
\hline $\begin{array}{l}\text { Fernanda } \\
\text { Góes, MD }\end{array}$ & $\begin{array}{l}\text { Neurology Pediatric Unit, } \\
\text { Pediatric Department, } \\
\text { Fernandes Figueira } \\
\text { Institute, Fiocruz, Brazil }\end{array}$ & $\begin{array}{l}\text { Major role in the acquisition } \\
\text { of data }\end{array}$ \\
\hline $\begin{array}{l}\text { Richard J. } \\
\text { Leventer, } \\
\text { MD, PhD }\end{array}$ & $\begin{array}{l}\text { Royal Childrens Hospital, } \\
\text { Melbourne, Australia }\end{array}$ & $\begin{array}{l}\text { Major role in the acquisition } \\
\text { of data }\end{array}$ \\
\hline
\end{tabular}


Appendix (continued)

\begin{tabular}{lll}
\hline Name & Location & Contribution \\
\hline $\begin{array}{l}\text { Davide } \\
\text { Colavito, MD }\end{array}$ & $\begin{array}{l}\text { Research \& Innovation S.r.l., } \\
\text { Padova, Italy }\end{array}$ & $\begin{array}{l}\text { Major role in the acquisition } \\
\text { of data }\end{array}$ \\
\hline $\begin{array}{l}\text { Sara Olivotto, } \\
\text { MD }\end{array}$ & $\begin{array}{l}\text { Pediatric Neurology Unit, V. } \\
\text { Buzzi Childrens Hospital, } \\
\text { Milan, Italy }\end{array}$ & $\begin{array}{l}\text { Major role in the acquisition } \\
\text { of data }\end{array}$ \\
\hline $\begin{array}{l}\text { Barbara } \\
\text { Scelsa, MD }\end{array}$ & $\begin{array}{l}\text { Pediatric Neurology Unit, V. } \\
\text { Buzzi Childrens Hospital, } \\
\text { Milan, Italy }\end{array}$ & $\begin{array}{l}\text { Major role in the acquisition } \\
\text { of data }\end{array}$ \\
\hline $\begin{array}{l}\text { Andrea V. } \\
\text { Andrade, MD }\end{array}$ & $\begin{array}{l}\text { Department of Paediatrics, } \\
\text { London Health Science } \\
\text { Centre/Schulich School of }\end{array}$ & $\begin{array}{l}\text { Major role in the acquisition } \\
\text { of data }\end{array}$ \\
& $\begin{array}{l}\text { Medicine and Dentisty, } \\
\text { University of Western } \\
\text { Ontario, London, ON, } \\
\text { Canada }\end{array}$
\end{tabular}

\begin{tabular}{ll}
\hline Kelly Ratke, & $\begin{array}{l}\text { Ambry Genetics, Aliso Viejo, } \\
\text { PhD }\end{array}$
\end{tabular}

PhD CA of data

Farha Tokarz, Advocate Lutheran General Major role in the acquisition MD Hospital, Park Ridge, IL of data

Atiya S. Khan, PPG Pediatric Neurology, Major role in the acquisition MD Parkview Health, Fort of data Wayne, IN

\begin{tabular}{lll}
\hline Clothilde & Department of Medical & Major role in the acquisition \\
Ormieres, MD & Genetics, AP-HP, Necker- & of data
\end{tabular}

Ormieres, MD Genetics, AP-HP, NeckerEnfants Malades Hospital, Paris, France

William Department of Neurology, Drafting/revision of the Benko, MD UC Davis, Sacramento, CA manuscript for content, including medical writing for content; Major role in the acquisition of data; Analysis or interpretation of data

\begin{tabular}{ll}
\hline Karen & Department of Pediatrics, \\
Keough, MD & Texas A\&M University \\
& Medical School, Austin
\end{tabular}

Drafting/revision of the manuscript for content, including medical writing for content; Study concept or design; Analysis or interpretation of data

\begin{tabular}{lll}
\hline Sotirios & Department of Pediatrics, & Drafting/revision of the \\
Keros, MD & Weill Cornell Medicine, New & manuscript for content, \\
& York, NY & including medical writing \\
& for content; Major role in \\
& the acquisition of data; \\
& $\begin{array}{l}\text { Analysis or interpretation } \\
\text { of data }\end{array}$
\end{tabular}

\begin{tabular}{|c|c|c|}
\hline $\begin{array}{l}\text { Shanawaz } \\
\text { Hussain, MD }\end{array}$ & $\begin{array}{l}\text { Leeds General Infirmary, } \\
\text { Leeds, United Kingdom }\end{array}$ & $\begin{array}{l}\text { Major role in the acquisition } \\
\text { of data }\end{array}$ \\
\hline $\begin{array}{l}\text { Ashlea } \\
\text { Franques, MD }\end{array}$ & $\begin{array}{l}\text { Thompson River Pediatrics, } \\
\text { Johnstown, CO }\end{array}$ & $\begin{array}{l}\text { Major role in the acquisition } \\
\text { of data }\end{array}$ \\
\hline $\begin{array}{l}\text { Felicia } \\
\text { Varsalone, } \\
\text { MD }\end{array}$ & $\begin{array}{l}\text { Pediatric Neurology Unit, V. } \\
\text { Buzzi Childrens Hospital, } \\
20154 \text { Milan, Italy }\end{array}$ & $\begin{array}{l}\text { Major role in the acquisition } \\
\text { of data }\end{array}$ \\
\hline $\begin{array}{l}\text { Sabine } \\
\text { Grønborg, } \\
\text { MD }\end{array}$ & $\begin{array}{l}\text { Department of } \\
\text { Neuropediatrics, University } \\
\text { Hospital Copenhagen, } \\
\text { Copenhagen, Denmark }\end{array}$ & $\begin{array}{l}\text { Major role in the acquisition } \\
\text { of data }\end{array}$ \\
\hline $\begin{array}{l}\text { Cyril Mignot, } \\
\text { MD, PhD }\end{array}$ & $\begin{array}{l}\text { APHP Trousseau, Paris, } \\
\text { France }\end{array}$ & $\begin{array}{l}\text { Major role in the acquisition } \\
\text { of data }\end{array}$ \\
\hline
\end{tabular}

Appendix (continued)

\begin{tabular}{lll}
\hline Name & Location & Contribution \\
\hline $\begin{array}{l}\text { Delphine } \\
\text { Heron, MD }\end{array}$ & $\begin{array}{l}\text { APHP Trousseau, Paris, } \\
\text { France }\end{array}$ & $\begin{array}{l}\text { Major role in the acquisition } \\
\text { of data }\end{array}$ \\
\hline $\begin{array}{l}\text { Caroline } \\
\text { Nava, MD, } \\
\text { PhD }\end{array}$ & $\begin{array}{l}\text { Department of Genetics, } \\
\text { Pitié-Salpêtrière hospital, } \\
\text { APHP, Sorbonne Université, } \\
\text { Paris, France }\end{array}$ & $\begin{array}{l}\text { Major role in the acquisition } \\
\text { of data }\end{array}$ \\
&
\end{tabular}

\begin{tabular}{lll}
\hline $\begin{array}{l}\text { Arnaud } \\
\text { Isapof, MD }\end{array}$ & $\begin{array}{l}\text { Service de Neuropédiatrie, } \\
\text { Hopital Trousseau, }\end{array}$ & $\begin{array}{l}\text { Major role in the acquisition } \\
\text { of data }\end{array}$ \\
& Sorbonne Université, & \\
& APHP.SU, Paris, France
\end{tabular}

\begin{tabular}{|c|c|c|}
\hline $\begin{array}{l}\text { Felippe } \\
\text { Borlot, MD }\end{array}$ & $\begin{array}{l}\text { Alberta Childrens Hospital, } \\
\text { Cumming School of } \\
\text { Medicine, University of } \\
\text { Calgary, Calgary, Alberta, } \\
\text { Canada; Division of } \\
\text { Neurology, Department of } \\
\text { Paediatrics, The Hospital for } \\
\text { Sick Children, Toronto, } \\
\text { Ontario, Canada }\end{array}$ & $\begin{array}{l}\text { Drafting/revision of the } \\
\text { manuscript for content, } \\
\text { including medical writing for } \\
\text { content; Major role in the } \\
\text { acquisition of data }\end{array}$ \\
\hline
\end{tabular}

\begin{tabular}{lll}
\hline $\begin{array}{l}\text { Robyn } \\
\text { Whitney, MD }\end{array}$ & $\begin{array}{l}\text { Division of Neurology, } \\
\text { Department of Paediatrics, } \\
\text { The Hospital for Sick } \\
\text { Children, Toronto, Ontario, } \\
\text { Canada }\end{array}$ & $\begin{array}{l}\text { Drafting/revision of the } \\
\text { manuscript for content, } \\
\text { including medical writing for } \\
\text { content; Major role in the } \\
\text { acquisition of data }\end{array}$ \\
\hline $\begin{array}{l}\text { Anne Ronan, } \\
\text { MD }\end{array}$ & $\begin{array}{l}\text { Hunter Genetics Unit, } \\
\text { Waratah, Australia }\end{array}$ & $\begin{array}{l}\text { Drafting/revision of the } \\
\text { manuscript for content, } \\
\text { including medical writing for } \\
\text { content; Major role in the } \\
\text { acquisition of data }\end{array}$
\end{tabular}

Nicola Wessex Clinical Genetics Drafting/revision of the

Foulds, MD Service, Princess Anne manuscript for content, Hospital, Southampton, including medical writing for United Kingdom content; Major role in the acquisition of data

\begin{tabular}{lll}
\hline Marta & KBO Kinderzentrum & $\begin{array}{l}\text { Drafting/revision of the } \\
\text { Somorai, MD }\end{array}$ \\
& Munchen, Munich, Germany & $\begin{array}{l}\text { manust for content, } \\
\text { including medical writing for } \\
\text { content; Major role in the } \\
\text { acquisition of data }\end{array}$
\end{tabular}

\begin{tabular}{lll}
\hline John & Division of Neurology, & Drafting/revision of the \\
Brandsema, & Epilepsy Neurogenetics & manuscript for content, \\
MD & Initiative, Childrens Hospital & including medical writing for \\
& of Philadelphia; Perelman & content; Analysis or \\
& $\begin{array}{l}\text { School of Medicine, } \\
\text { Philadelphia, PA }\end{array}$ & interpretation of data \\
&
\end{tabular}

\begin{tabular}{lll}
\hline Katherine L. & $\begin{array}{l}\text { Division of Neurology, } \\
\text { Helbig, MSc }\end{array}$ & $\begin{array}{l}\text { Major role in the acquisition } \\
\text { Initiative, Childrens Hospital } \\
\text { of Philadelphia, PA }\end{array}$
\end{tabular}

Ingo Helbig, Division of Neurology, Drafting/revision of the

MD, PhD Epilepsy Neurogenetics manuscript for content,
Initiative, Childrens Hospital including medical writing for of Philadelphia, PA; PURA content; Major role in the Syndrome Foundation, acquisition of data; Analysis Greensborough, Australia; $\quad$ or interpretation of data; PURA Syndrome Obtaining funding Foundation, Kansas City, $\mathrm{MO}$

\begin{tabular}{lll}
\hline $\begin{array}{l}\text { Xilma R. } \\
\text { Ortiz- }\end{array}$ & $\begin{array}{l}\text { Division of Neurology, } \\
\text { Epilepsy Neurogenetics }\end{array}$ & $\begin{array}{l}\text { Major role in the acquisition } \\
\text { of data }\end{array}$ \\
$\begin{array}{ll}\text { González, MD } \\
\text { Initiative, Childrens } \\
\text { Hospital of Philadelphia, } \\
\end{array}$ & \\
\hline
\end{tabular}


Appendix (continued)

\begin{tabular}{lll}
\hline Name & Location & Contribution \\
\hline Holly Dubbs, & $\begin{array}{l}\text { Division of Neurology, } \\
\text { Epilepsy Neurogenetics } \\
\text { Initiative, Childrens Hospital } \\
\text { of Philadelphia, PA }\end{array}$ & $\begin{array}{l}\text { Drafting/revision of the } \\
\text { manuscript for content, } \\
\text { including medical writing for } \\
\text { content; Major role in the } \\
\text { acquisition of data }\end{array}$
\end{tabular}

\begin{tabular}{ll}
\hline Antonio & INSERM UMR1231, GAD \\
Vitobello, & team, Universit'e de \\
PhD & Bourgogne-Franche Comt' \\
& e, Dijon, France; Unit'e \\
& Fonctionnelle dlnnovation \\
& diagnostique des maladies \\
& rares, Pole de Biologie, FHU- \\
& TRANSLAD, CHU Dijon \\
& Bourgogne, Dijon, France
\end{tabular}

\begin{tabular}{ll}
\hline Mel & PURA Syndrome \\
Anderson, & Foundation, \\
MSc & Greensborough, Australia
\end{tabular}

Analysis or interpretation of data; Obtaining funding

\section{Drafting/revision of the} manuscript for content, including medical writing for content; Major role in the acquisition of data; Analysis or interpretation of data

\begin{tabular}{lll}
\hline Dominic & PURA Syndrome & Major role in the acquisition \\
Spadafore, & Foundation, & of data \\
MSc & Greensborough, Australia; & \\
& PURA Syndrome & \\
& Foundation, Kansas City, \\
& MO
\end{tabular}

\begin{tabular}{lll}
\hline David Hunt, & Wessex Clinical Genetics & Major role in the acquisition \\
MD & Service, Princess Anne & of data \\
& Hospital, Southampton, & \\
& United Kingdom &
\end{tabular}

\begin{tabular}{|c|c|c|}
\hline $\begin{array}{l}\text { Rikke S. } \\
\text { Møller, MSc, } \\
\text { PhD }\end{array}$ & $\begin{array}{l}\text { Department of Epilepsy } \\
\text { Genetics and Personalized } \\
\text { Treatment, The Danish } \\
\text { Epilepsy Centre Filadelfia, } \\
\text { Dianalund, Denmark; } \\
\text { Institute for Regional Health } \\
\text { Research, University of } \\
\text { Southern Denmark, } \\
\text { Odense, Denmark }\end{array}$ & $\begin{array}{l}\text { Drafting/revision of the } \\
\text { manuscript for content, } \\
\text { including medical writing for } \\
\text { content; Study concept or } \\
\text { design; Analysis or } \\
\text { interpretation of data }\end{array}$ \\
\hline $\begin{array}{l}\text { Guido } \\
\text { Rubboli, MD, } \\
\text { PhD }\end{array}$ & $\begin{array}{l}\text { The Danish Epilepsy Center } \\
\text { Filadelfia/University of } \\
\text { Copenhagen, Dianalund, } \\
\text { Denmark }\end{array}$ & $\begin{array}{l}\text { Drafting/revision of the } \\
\text { manuscript for content, } \\
\text { including medical writing for } \\
\text { content; Major role in the } \\
\text { acquisition of data; Study } \\
\text { concept or design; Analysis } \\
\text { or interpretation of data; } \\
\text { Study supervision or } \\
\text { coordination }\end{array}$ \\
\hline
\end{tabular}

\section{References}

1. Geer LY, Marchler-Bauer A, Geer RC, et al. The NCBI BioSystems database. Nucleic Acids Res. 2010;38(Data issue):D492-D496.

2. Tanaka AJ, Bai R, Cho MT, et al. De novo mutations in PURA are associated with hypotonia and developmental delay. Cold Spring Harbor Mol Case Stud. 2015;1(1): a000356.

3. Khalili K, Del Valle L, Muralidharan V, et al. Puralpha is essential for postnatal brain development and developmentally coupled cellular proliferation as revealed by genetic inactivation in the mouse. Mol Cell Biol. 2003;23(19):6857-6875.

4. Barbe MF, Krueger JJ, Loomis R, Otte J, Gordon J. Memory deficits, gait ataxia and neuronal loss in the hippocampus and cerebellum in mice that are heterozygous for Pur-alpha. Neuroscience. 2016;337:177-190.

5. Lee BH, Reijnders MRF, Abubakare O, et al. Expanding the neurodevelopmental phenotype of PURA syndrome. Am J Med Genet A. 2018;176(1):56-67.

6. Rodríguez-García ME, Cotrina-Vinagre FJ, Arranz-Canales E, et al. A novel de novo mutation in the PURA gene associated with a new clinical finding: large brainstem. J Genet. 2020;99:7.

7. Reijnders MRF, Janowski R, Alvi M, et al. PURA syndrome: clinical delineation and genotype-phenotype study in 32 individuals with review of published literature. J Med Genet. 2018;55(2):104-113.
8. Lalani SR, Zhang J, Schaaf CP, et al. Mutations in PURA cause profound neonata hypotonia, seizures, and encephalopathy in 5q31.3 microdeletion syndrome. Am J Hum Genet. 2014;95(5):579-583.

9. Mayorga L, Gamboni B, Mampel A, Roqué M. A frame-shift deletion in the PURA gene associates with a new clinical finding: hypoglycorrhachia. Is GLUT1 a new PURA target? Mol Genet Metab. 2018;123(3):331-336.

10. Hunt D, Leventer RJ, Simons C, et al. Whole exome sequencing in family trios reveals de novo mutations in PURA as a cause of severe neurodevelopmental delay and learning disability. J Med Genet. 2014;51(12):806-813.

11. Rezkalla J, Von Wald T, Hansen KA. Premature thelarche and the PURA syndrome. Obstet Gynecol. 2017;129(6):1037-1039.

12. Okamoto N, Nakao H, Niihori T, Aoki Y. Patient with a novel purine-rich element binding protein A mutation. Congenit Anom. 2017;57(6):201-204.

13. Qiao Y, Bagheri H, Tang F, et al. Exome sequencing identified a de novo mutation of PURA gene in a patient with familial Xp22.31 microduplication. Eur J Med Genet. 2019;62(2):103-108.

14. Trau SP, Pizoli CE. PURA syndrome and myotonia. Pediatr Neurol. 2020;104:62-63.

15. Brown N, Burgess T, Forbes R, et al. 5q31.3 Microdeletion syndrome: clinical and molecular characterization of two further cases. Am J Med Genet A. 2013;161A(10):2604-2608

16. Richards S, Aziz N, Bale S, et al. Standards and guidelines for the interpretation of sequence variants: a joint consensus recommendation of the American College of Medical Genetics and Genomics and the Association for Molecular pathology. Genet Med. 2015; 17(5):405-424.

17. Scheffer IE, Berkovic S, Capovilla G, et al. ILAE classification of the epilepsies: position paper of the ILAE Commission for Classification and terminology. Epilepsia. 2017;58(4):512-521.

18. Fisher RS, Cross JH, French JA, et al. Operational classification of seizure types by the International League Against Epilepsy: position paper of the ILAE Commission for Classification and terminology. Epilepsia. 2017;58(4):522-530.

19. Mishra M, Del Valle L, Otte J, Darbinian N, Gordon J. Pur-alpha regulates RhoA developmental expression and downstream signaling. J Cell Physiol. 2013;228(1):65-72.

20. Kobayashi $Y$, Tohyama J, Kato M, et al. High prevalence of genetic alterations in earlyonset epileptic encephalopathies associated with infantile movement disorders. Brain Dev. 2016;38(3):285-292

21. Sanger TD, Chen D, Fehlings DL, et al. Definition and classification of hyperkinetic movements in childhood. Mov Disord. 2010;25(11):1538-1549.

22. Gardella E, Marini C, Trivisano M, et al. The phenotype of SCN8A developmental and epileptic encephalopathy. Neurology. 2018;91(12):e1112-e1124.

23. Papandreou A, Schneider RB, Augustine EF, et al. Delineation of the movement disorders associated with FOXG1 mutations. Neurology. 2016;86(19):1794-1800.

24. Nakamura K, Kodera H, Akita T, et al. De Novo mutations in GNAO1, encoding a Gao subunit of heterotrimeric $\mathrm{G}$ proteins, cause epileptic encephalopathy. Am J Hum Genet. 2013;93(3):496-505.

25. Milh M, Villeneuve N, Chouchane M, et al. Epileptic and nonepileptic features in patients with early onset epileptic encephalopathy and STXBP1 mutations. Epilepsia. 2011;52(10):1828-1834.

26. Gorman KM, Meyer E, Grozeva D, et al. Bi-allelic loss-of-function CACNA1B Mutations in progressive Epilepsy-dyskinesia. Am J Hum Genet. 2019;104(5):948-956.

27. Goldman S, Wang C, Salgado MW, Greene PE, Kim M, Rapin I. Motor stereotypies in children with autism and other developmental disorders. Dev Med child Neurol. 2009;51(1):30-38.

28. Bakker MJ, van Dijk JG, van den Maagdenberg AM, Tijssen MA. Startle syndromes. Lancet Neurol. 2006;5(6):513-524.

29. Hortigüela M, Fernández-Marmiesse A, Cantarín V, et al. Clinical and genetic features of 13 Spanish patients with KCNQ2 mutations. J Hum Genet. 2017;62(2):185-189.

30. Bonaglia MC, Zanotta N, Giorda R, D'Angelo G, Zucca C. Long-term follow-up of a patient with $5 \mathrm{q} 31.3$ microdeletion syndrome and the smallest de novo $5 \mathrm{q} 31.2 \mathrm{q} 31.3$ deletion involving PURA. Mol Cytogenet. 2015;8:89.

31. Cooper MS, McIntosh A, Crompton DE, et al. Mortality in Dravet syndrome. Epilepsy Res. 2016;128:43-47.

32. Johannesen KM, Gardella E, Scheffer I, et al. Early mortality in SCN8A-related epilepsies. Epilepsy Res. 2018;143:79-81.

33. Hokkanen S, Feldmann HM, Ding H, et al. Lack of Pur-alpha alters postnatal brain development and causes megalencephaly. Hum Mol Genet. 2012;21(3):473-484.

34. Hart TC, Hart PS. Genetic studies of craniofacial anomalies: clinical implications and applications. Orthod Craniofac Res. 2009;12(3):212-220.

35. Ferry Q, Steinberg J, Webber C, et al. Diagnostically relevant facial gestalt information from ordinary photos. eLife. 2014;3:e02020.

36. Basel-Vanagaite L, Wolf L, Orin M, et al. Recognition of the Cornelia de Lange syndrome phenotype with facial dysmorphology novel analysis. Clin Genet. 2016; 89(5):557-563.

37. Kessi M, Peng J, Yang L, et al. Genetic etiologies of the electrical status epilepticus during slow wave sleep: systematic review. BMC Genet. 2018;19(1):40.

38. Lesca G, Møller RS, Rudolf G, Hirsch E, Hjalgrim H, Szepetowski P. Update on the genetics of the epilepsy-aphasia spectrum and role of GRIN2A mutations. Epileptic Disord. 2019;21(S1):41-47

39. Symonds JD, Zuberi SM, Stewart K, et al. Incidence and phenotypes of childhoodonset genetic epilepsies: a prospective population-based national cohort. Brain. 2019; 142(8):2303-2318.

40. Johannesen KM, Nikanorova N, Marjanovic D, et al. Utility of genetic testing for therapeutic decision-making in adults with epilepsy. Epilepsia. 2020;61(6):1234-1239.

41. Weber J, Bao H, Hartlmuller C, et al. Structural basis of nucleic-acid recognition and double-strand unwinding by the essential neuronal protein Pur-alpha. eLife. 2016;5: e11297. 


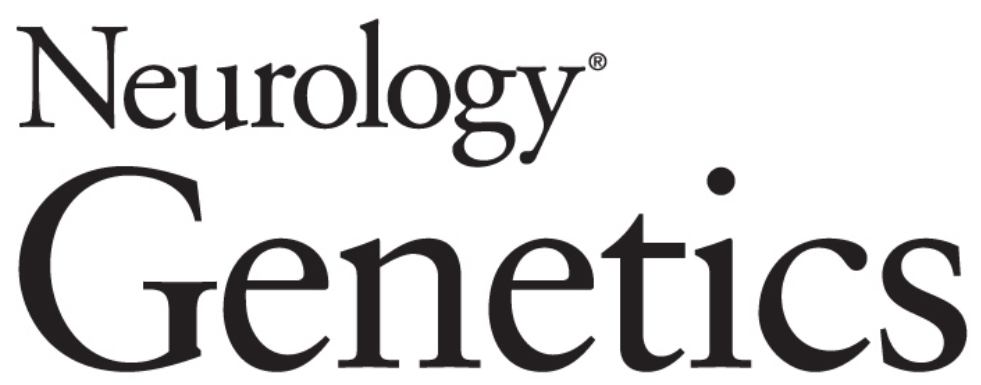

\section{PURA-Related Developmental and Epileptic Encephalopathy: Phenotypic and Genotypic Spectrum \\ Katrine M. Johannesen, Elena Gardella, Cathrine E. Gjerulfsen, et al. Neurol Genet 2021;7; \\ DOI 10.1212/NXG.0000000000000613}

This information is current as of November 15, 2021

Neurol Genet is an official journal of the American Academy of Neurology. Published since April 2015, it is an open-access, online-only, continuous publication journal. Copyright Copyright $\odot 2021$ The Author(s). Published by Wolters Kluwer Health, Inc. on behalf of the American Academy of Neurology.. All rights reserved. Online ISSN: 2376-7839.

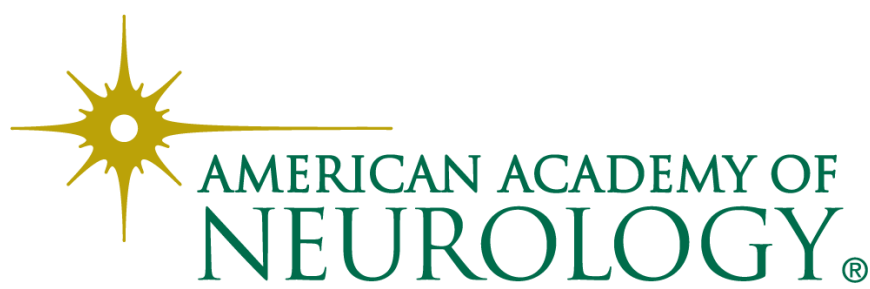




\section{Updated Information \& Services}

References

Citations

Subspecialty Collections

Permissions \& Licensing

Reprints including high resolution figures, can be found at: http://ng.neurology.org/content/7/6/e613.full.html

This article cites 41 articles, 3 of which you can access for free at: http://ng.neurology.org/content/7/6/e613.full.html\#\#ref-list-1

This article has been cited by 3 HighWire-hosted articles: http://ng.neurology.org/content/7/6/e613.full.html\#\#otherarticles

This article, along with others on similar topics, appears in the following collection(s):

All Epilepsy/Seizures

http://ng.neurology.org//cgi/collection/all_epilepsy_seizures All Genetics

http://ng.neurology.org//cgi/collection/all_genetics

Developmental disorders

http://ng.neurology.org//cgi/collection/developmental_disorders

Information about reproducing this article in parts (figures,tables) or in its entirety can be found online at:

http://ng.neurology.org/misc/about.xhtml\#permissions

Information about ordering reprints can be found online:

http://ng.neurology.org/misc/addir.xhtml\#reprintsus

Neurol Genet is an official journal of the American Academy of Neurology. Published since April 2015, it is an open-access, online-only, continuous publication journal. Copyright Copyright $\odot 2021$ The Author(s). Published by Wolters Kluwer Health, Inc. on behalf of the American Academy of Neurology.. All rights reserved. Online ISSN: 2376-7839.

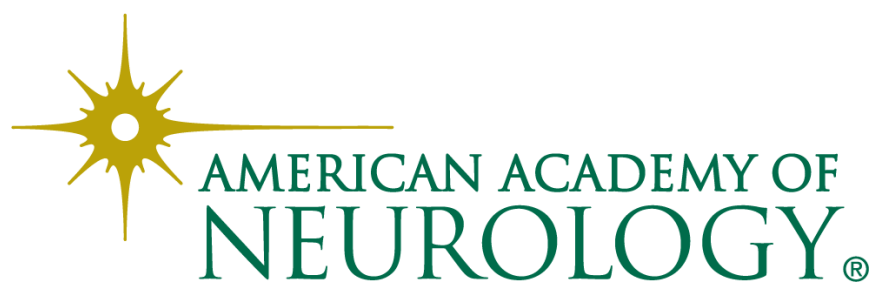

